\title{
Early Miocene small mammals from MWQ1/2001 Turtle Joint (Mokrá-Quarry, South Moravia, Czech Republic): biostratigraphical and palaeoecological considerations
}

\author{
IsaAc Bonilla-Salomón, Stanislav Čermák, Àngel H. Luján, Ivan HoráČek, \\ Martin IVANOV \& Martin SABOL
}

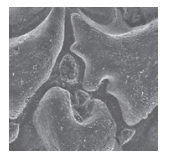

\begin{abstract}
Mokrá-Quarry (South Moravia, Czech Republic) represents a unique fossil site with an extraordinary abundance and diversity of vertebrate fossil remains. Most research on Mokrá-Quarry localities was focused on herpetofauna. Despite its relevance, the mammal fauna has not been yet studied in detail. In this work, the small mammals from one of the karstic fissures, Mokrá-Western Quarry (1/2001 Turtle Joint), are thoroughly described for the first time, including eight different taxa: Prolagus schnaitheimensis, Prolagus $\mathrm{cf}$. vasconinensis, Rhinolophus $\mathrm{cf}$. cluzeli, Rhinolophus cf. grivensis, Galerix sp., Aliveria aff. luteyni, Megacricetodon sp., and Melissiodon dominans. The Megacricetodon finds represent one of the first appearances of this cricetid in Central Europe and sheds light on the early evolution of the genus. Moreover, the small mammal assemblage confirms an early Miocene age (Burdigalian, MN4) for MWQ1/2001. The paleoenvironment inferred shows a dry karst landscape, with patches of woodlands and open steppe, together with marshy areas. - Key words: Lagomorpha, Rodentia, Chiroptera, Eulipotyphla, Carpathian Foredeep Basin, Moravian Karst.
\end{abstract}

Bonilla-Salomón, I., Čermák, S., Luján, À.H., HoráČEK, I., Ivanov, M. \& Sabol, M. 2021. Early Miocene small mammals from MWQ1/2001 Turtle Joint (Mokrá-Quarry, South Moravia, Czech Republic): biostratigraphical and palaeoecological considerations. Bulletin of Geosciences 96(1), 99-122 (9 figures, 2 tables). Czech Geological Survey, Prague. ISSN 1214-1119. Manuscript received Mai 28, 2020; accepted in revised form November 25, 2020; published online December 20, 2020; issued January 10, 2021.

\begin{abstract}
Isaac Bonilla-Salomón \& Martin Sabol, Comenius University, Faculty of Natural Science, Department of Geology and Paleontology, Mlynská dolina, Ilkovičova Str. 6, SK-84215 Bratislava, Slovak Republic; salomon1@uniba.sk•Stanislav Čermák, Institute of Geology of the Czech Academy of Sciences, Rozvojová 269, 16500 Prague 6, Czech Republic • Àngel H. Luján, Masaryk University, Faculty of Science, Department of Geological Sciences, Kotlářská 267/2, 611 37 Brno, Czech Republic \& Institut Català de Paleontologia Miquel Crusafont, Universitat Autònoma de Barcelona, Edifici ICTA, c/ Columnes s/n, Campus de la UAB, 08193 Cerdanyola del Vallès, Barcelona, Spain; angel.lujan@icp.cat•Ivan Horáček, Charles University, Faculty of Science, Department of Zoology, Viničná 7, CZ-12844 Praha 2, Czech Republic • Martin Ivanov, Masaryk University, Faculty of Science, Department of Geological Sciences, Kotlářská 267/2, 61137 Brno, Czech Republic
\end{abstract}

Early Miocene fossil mammal assemblages are quite frequent in Central Europe, however, only nine localities are known from the territory of the Czech Republic (Cicha et al. 1972; Fejfar, 1974, 1990; Fejfar \& Roček 1986; Fejfar \& Kvaček, 1993; Fejfar et al. 2003; Ekrt et al. 2016). The older ones come from the early Burdigalian deposits of the main brown coal seam of Ahníkov/Merkur Mine (early MN3a) and the limestone quarry of Tuchořice (MN3b), both located in the Most Basin (Ohře/Eger Graben, NW Czech Republic) and of early Burdigalian (Eggenburgian) in age. Regarding MN4 sites, the three Dolnice localities (Dolnice 1-3) from the Cheb Basin (Burdigalian, late Ottangian-Karpatian) have yielded abundant vertebrate remains (Fejfar 1974, 1990; Fejfar \& Kvaček 1993). As for the South Moravian Region, the site of Orrechov was correlated with the MN4 zone (late
Ottnangian, Burdigalian) based on the data obtained from micromammals (Cicha et al. 1972, Fejfar 1990). However, the most recent fossil bearing site discovered in the Czech Republic is the open-cast limestone mine of Mokrá-Quarry, which is placed $12 \mathrm{~km}$ ENE of Brno city. It is located on the Mokrá Plateau, situated in the SE of the Moravian Karst, close to the margin fault of the West Carpathian Foredeep. The Mokrá Plateau is mostly formed by the massive and biodetritic Vilémovice Limestone (GivetianFrasnian) of the Macocha Formation (Ivanov et al. 2006). The western part of the Mokrá-Quarry is mainly made up by the Vilémovice Limestone, whereas the central part of the quarry is formed also by the Hády-Ríčka Limestone and the Krrtiny Limestone of the Líšeň Formation, as well as breccia and sandy limestones with shales of the Březina Formation (Rez 2010). Those carbonates, which pass into 
the lower Carboniferous flysch facies, are often affected by several phases of folding due to the Paleozoic orogeny. The chemical character of the carbonates, together with the process of pressure dissolution and the mechanical deformation (Hladil et al. 1987; Rez 2003, 2010), are the main factors responsible of karstic landscape of MokráQuarry.

In the southern part of the Moravian Karst, Neogene freshwater and brackish sediments of Ottnangian age, together with Badenian deltaic sands, gravels and marine clays, are abundant. Even though marine sediments dominated the Carpathian Foredeep in the South Moravia Region during the Karpatian stage, those sediments are not preserved in the southern part of the Moravian Karst. The Badenian transgression affected the majority of the Drahany Upland and the Moravian Karst (Procházka 1899, Brzobohatý 1997). Remnants of those sediments occur in karst fissures, as confirmed by several boreholes located between the central and western quarries, which yielded rich remains of foraminiferans, ostracods, sponge spicules and fish otoliths (Brzobohatý et al. 2000).

Indeed, Mokrá-Quarry consists of three separated quarries: the western (MWQ), the central (MCQ), and the eastern one (MEQ: Fig. 1). Several karst fissures have been located in central and western quarries, one yielding a rich assemblage of the early Pleistocene age (Fejfar \& Horáček 1983). At the beginning of $21^{\text {st }}$ century, commercial extraction works started (Ivanov \& Musil 2004, Ivanov et al. 2006), leading to the discovery of two fossiliferous karst fissures in the western quarry: $1 / 2001$ Turtle Joint (hereinafter MWQ1/2001), and 2/2003 Reptile Fissure (hereinafter MWQ2/2003). The last years of research in Mokrá-Quarry have provided three more localities, which are the following: MCQ3/2005 from the central quarry; MWQ-TC4/2001 and MWQ4/2018 from the western quarry. It is noteworthy that turtle fossil remains are especially abundant in the above-mentioned localities (see Luján et al. 2017, in press). In any case, all research efforts in Mokrá-Quarry have been focused on the herpetofauna to date. According to Ivanov (2008), thirteen different amphibian taxa were reported from both fissures MWQ1/2001 and MWQ2/2003, including the first records of the West European species of Triturus cf. marmoratus and Chioglossa meini in Central Europe as early as MN4. Moreover, the recent description of a new species of varanid, Varanus mokrensis from MWQ1/2001 and MWQ2/2003, provided the first documented example of a European varanid for which osteological data allowed a well-supported assignment at the genus level (Ivanov et al. 2018, Villa et al. 2018). Regarding mammals, the first preliminary ascriptions of some medium-sized specimens were conducted by Ivanov and Musil (2004). Shortly after, a faunal list of medium-sized and large mammals from
MWQ1/2001 and MWQ2/2003 was published (Ivanov et al. 2006), but neither descriptions nor measurements of the fossil material were provided. As for small mammals, only a preliminary study of the material from MWQ1/2001 was conducted by Sabol et al. (2007).

In this work, all micromammal remains from MWQ1/2001 were revised for the first time. Moreover, a thorough discussion on the age of this fossil assemblage and its paleoecological conditions are assessed.

\section{Material and methods}

Terminology. - The micromammal fauna from 1/2001 was discovered during the field campaigns leaded by $\mathrm{M}$. Ivanov and R. Musil from the Masaryk University (Brno, Czech Republic) during the years 2002-2005. The remains were obtained by washing the fossil material, mixed in sand and clays, in sieves of $0.5 \mathrm{~mm}$ mesh (Ivanov et al. 2006). Currently, the material is housed in the collections of the Department of Geological Sciences (Faculty of Science, Masaryk University) under the inventory numbers SMM/009-09-11/ 372009, Pal. 3000-3846. Upper cheek teeth are indicated by upper case letters (P4, M1, M2, M3) and lower cheek teeth by lower case (p4, m1, m2, $\mathrm{m} 3$ ). When distinction between first and second molars is dubious, these are indicated as M1/2 or $\mathrm{m} 1 / 2$.

Dental terminology and metrics employed in the present work follow the next authors: Sciuridae (CuencaBescós 1988); Cricetidae (Oliver \& Peláez-Campomanes 2013); Erinaceidae (Engesser 1980); Chiroptera (Hand 1985, Horáček \& Špoutil 2012); Lagomorpha (LopézMartínez 1989, Angelone \& Sesé 2009, Hordijk \& van der Meulen 2010a, Hordijk et al. 2010). Lagomorpha drawings and measures were taken with the aid of a DinoLite digital microscope.

Dental measurements of lagomorphs were taken only in adult specimens (recognized by their prismatic tooth shape), as maximum antero-posterior or bucco-lingual dimensions of the respective two-dimensional dental structures orthogonal to prismatic shaft. For the rest of groups, all measurements were taken with the Carl Zeiss Stemi 305 microscope and the Carl Zeiss W-PI 10x/23 Microscope Focusable Eyepiece, providing cheek teeth occlusal surface maximum length and width $(\mathrm{L} \times \mathrm{W})$. All measured data are given in millimetres $(\mathrm{mm})$. Micrographs were taking using the JSM-6390 Scanning Electron Microscope (SEM) at the Earth Science Institute in Banská Bystrica (Slovakia).

Neogene time scales boundaries follow the International Chronostratographic Chart v2020/03 (www. stratigraphy.org). MN zones, where their boundaries are defined based on selected appearance events, follows Hilgen et al. (2012) in general. We follow Hilgen et al. 
Figure 1. Location of MokráQuarry. - A - geographical position of Mokrá-Quarry. • B schematic global map of the Czech Republic. $・ \mathrm{C}$ - position of $1 / 2001$ in Mokrá-Quarry. Modified from Luján et al. (in press, fig. 1).
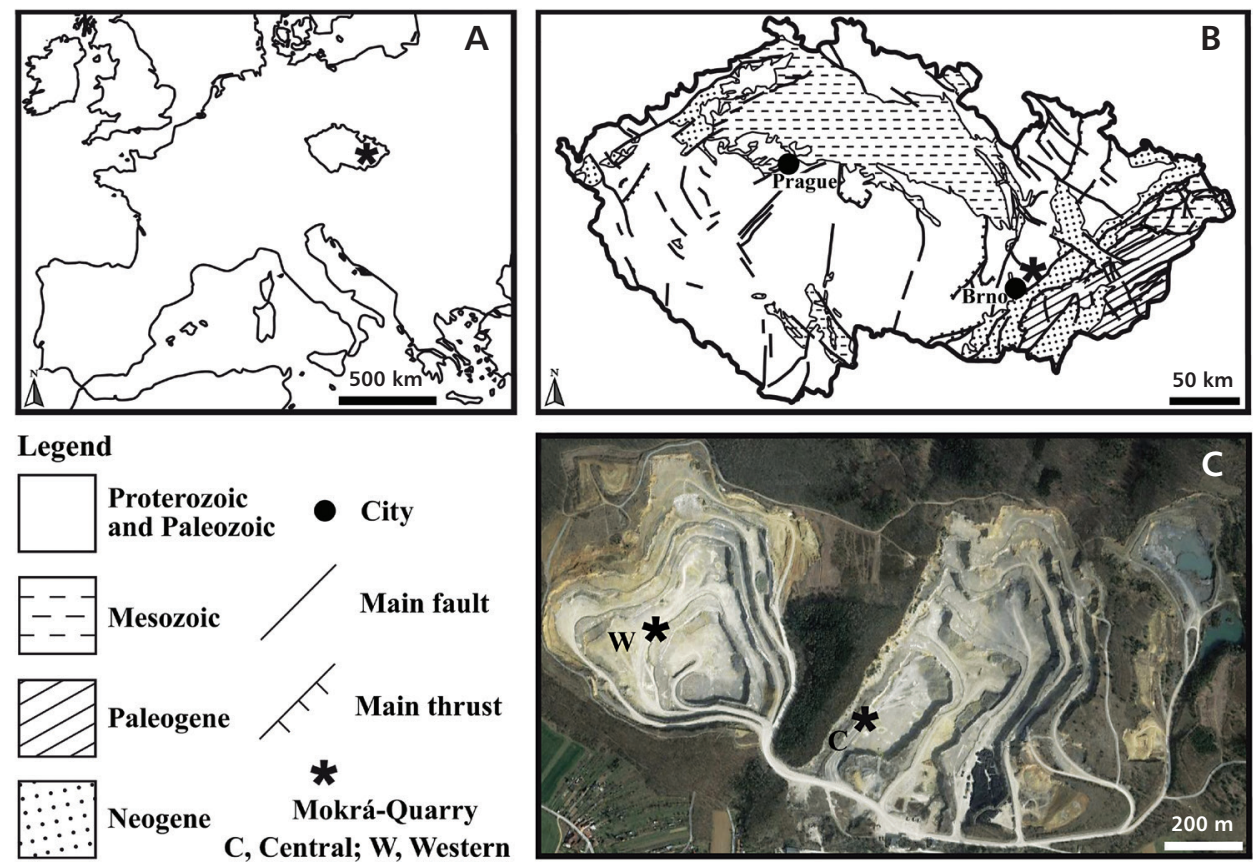

(2012) for defining the basis for MN3 and MN5, but Steininger (1999) for MN4.

Measurements and locality abbreviations. - Measurements abbreviations: AA - partial width; CV - coefficient of variation [\%]; $\mathrm{L}$ - length; $\mathrm{La}$ - anteroconid length; Lme metaconid-entoconid length; Lpl - postlobus length; Ltrig - trigonid length; $\mathrm{L} \times \mathrm{W}$ - maximum length and width of the cheek tooth occlusal surface; $\mathrm{M} / \mathrm{m}$ - upper/ lower molar; $\mathrm{N}$ - number of specimens; OR - observed range; $\mathrm{P} / \mathrm{p}$ - upper/lower premolar; $\mathrm{PH}$ - hypoflexus width; $\mathrm{TH}$ - distal hyperloph length; $\mathrm{W}$ - width; $\mathrm{Wa}$ - anteroconid width; Wdh - precone-distal hypercone width; Wtl - third lobe width of $\mathrm{m} 2$; Wtal - talonid width; Wtrig - trigonid width; $\overline{\mathrm{x}}$ - arithmetic mean.

Locality abbreviations: MWQ1/2001 - Mokrá-Western Quarry 1/2001 Turtle Joint (MN4); MWQ2/2003 Mokrá-Western Quarry 2/2003 Reptile Fissure (MN4).

\section{Systematic palaeontology}

Class Mammalia Linnaeus, 1758

Order Lagomorpha Brandt, 1855

Famil: Prolagidae Gureev, 1960

\section{Genus Prolagus Pomel, 1853}

Discussion. - Lagomorphs from MWQ1/2001 are exclusively represented by isolated teeth. The combination of the following discriminant features clearly supports their attribution to the sole genus Prolagus: (i) the complete rootless hypsodonty in permanent teeth; (ii) isolated anteroconid in $\mathrm{p} 3$; (iii) absence of $\mathrm{m} 3$; (iv) hypoconulid in $\mathrm{m} 2$; (v) P2 with distinct meso- and paraflexus; (vi) P3 with well-developed paraflexus and mesoflexus; (vii) enamel fossettes in P4-M2. Two distinct species of Prolagus (P. schneitheimensis and $P$. cf. vasconiensis) were distinguished in MWQ1/2001 assemblage, well differing from each other by the size, curvature, and relative length of tooth shafts; size and morphology of $\mathrm{p} 3$ anteroconid; complexity of $\mathrm{p} 3$ protoconid; size and morphology of P4-M2 fossettes; and length of M1-M2 hypoflexus (see "Descriptions" for details).

The lagomorph fauna of MWQ1/2001 comprises predominantly (ca. 85\%) the species $P$. schnaitheimensis, which is characterized particularly by: straight and short p3 shaft without antero-posterior bending; very shallow p3 centroflexid; simple p3 protoconid; short P4-M2 shafts with a small radius of linguo-buccal curvature. This fossil lagomorph represents one of the prolagid lineages that evolved in the "cricetid vacuum", which was first described by Tobien (1975) from the early Miocene locality Schnaitheim (MN3, Germany). The species is also known from many other MN3-MN4 localities of Central Europe (see e.g. Tobien 1975, Ziegler \& Fahlbusch 1986, Sabol et al. 2007). The material presented here is fully compatible with the one from the type locality, except for: a higher degree of evolution of M1-M2 parafossettes and P3 lagiloph; the predominantly bifurcated P3 parafossette with more plicated enamel walls; the longer lagiloph; and the shorter mesial hyperloph. These features are most 
similar to Prolagus recorded from the localities Limberg and Echzell (Tobien, 1975). Two M1 specimens in the material under study possess highly crenulated enamel walls of parafossette (Fig. 2O), resembling Ptychoprolagus forsthartensis, a descendant of P. schnaitheimensis (Tobien 1975, López Martínez 2001, Hordijk et al. 2010). However, the mentioned parafossettes from MWQ1/2001 are much less crenulated than those in the type material originally described by Tobien (1975) from the MN4 locality Forsthart (Germany). Taking into account the largely accepted ancestor-descendant relationship of P. schnaitheimensis and Ptychoprolagus forsthartensis and the simple not crenulated fossettes significantly prevailing in the whole material from MWQ1/2001, these two specimens are regarded here as extreme variants within the morphological range of the species P. schnaitheimensis. The morphology of $\mathrm{p} 3$ in the schnaitheimensis-lineage seems to be quite conservative; in fact, the species of this clade never evolved a deep $\mathrm{p} 3$ centroflexid and $\mathrm{p} 3$ protoconid retained generally simple, mostly rounded without protoconulid.

Specimens referred here to Prolagus cf. vasconiensis represent about the $11 \%$ of the material from MWQ $1 / 2001$. The taxonomically important features in the available material, such as the long and antero-posteriorly bent $\mathrm{p} 3$, very shallow $\mathrm{p} 3$ centroflexid with protoconidmetaconid connection, small p3 anteroconid, simple p3 protoconid with short protoflexid and incipient protoconulid, short $\mathrm{P} 4-\mathrm{M} 2$ shafts with a small radius of linguo-buccal curvature, and reduced simple P4-M2 fossettes are fully compatible with the species: Prolagus vasconiensis and P. lopezmartinezae. The former species, described by Viret in Roman \& Viret (1930) from the MN3 locality of Estrepouy (France), was widespread throughout Central-Western Europe from the Czech Republic to Spain (Boon-Kristkoiz \& Kristkoiz 1999), and further it is regarded to be the last common ancestor of all subsequent lineages of Prolagus which arose during the early Miocene (López-Martínez 1997). The latter species was described by Hordijk \& van der Meulen (2010a) from the early Miocene (MN4; local Zone B) locality of San Marcos (Spain), and at present, it is only known from Spanish localities (Hordijk et al. 2015). Hordijk \& van der Meulen (2010a) consider P. lopezmartinezae to be an intermediate chronospecies within the Iberian endemic evolution of $P$. vasconiensis to $P$. tobieni. In their view, $P$. lopezmartinezae differs from $P$. vasconiensis in having a particular combination of features such as the $\mathrm{P} 3$ lagicone without a long lagiloph, less curved and generally shorter P3 mesoflexus, and slightly more reduced enamel fossettes in the upper molars. Nevertheless, the first two features were recognized not only in the very limited material from MWQ1/2001, but also in the material from the type locality of Estrepouy (MN3) of P. vasconiensis, including the type series described by Viret in Roman \& Viret (1930, fig. 7b) and additional material described by Tobien (1975, fig. 58). The material from the older locality of Laugnac (MN2) presented by Tobien (1975) shows, on the other hand, more developed P3 lagiloph and longer and more curved P3 mesoflexus; this may indicate similar morphoclines (reduction of the lagiloph in the P3 and enlargement and bending of the mesoflexus), such as in the Iberian vasconiensis-tobieni lineage. However, we are aware that the compositions of particular morphotypes of particular teeth within European populations of the vasconiensis-oeningensis lineage are not yet known. Moreover, it should be noted that an evolution of prolagids, having considerable intra-specific and ontogenetic variation, is not generally straightforward due to mosaic, convergent, and parallel trends and/or changes (López Martínez 1989, 1997; Hordijk et al. 2010). Thus, we tentatively accept the hypothesis by Hordijk et al. (2010) that the Iberian P. lopezmartinezae lineage and western Central European P. oeningensis lineage evolved from $P$. vasconiensis in allopatry, both reflecting anagenetic trends; i.e. that the Prolagus vasconiensis-P. lopezmartinezae- $P$. tobieni lineage is endemic to the Iberian Peninsula. In this context, we co-identify here, pro tempore, the second species from MWQ1/2001 with the nominal taxon described by Viret in Roman \& Viret (1930) from the MN3 locality of Estrepouy and refer the taxon under study as $P$. cf. vasconiensis.

\section{Prolagus schnaitheimensis Tobien, 1975}

Figure 2A-I, O

Material. - One left P2 (Pal. 3071); 6 left P3 [Pal. 3072-77 (juv.)]; six right P3 (Pal. 3078-82, Pal. 3231); eight left P4 (Pal. 3083-90); three right P4 [Pal. 3091-92 (juv.), Pal. 3093]; three left M1 (Pal. 3094-96); seven right M1 (Pal. 3097-3103); two left M2 (Pal. 3104-05); four right M2 (Pal. 3106-09); two left M1/M2 (Pal. 3110-11); three right M1/M2 (Pal. 3112-14); eleven left p3 [Pal. 3037-43, Pal. 3045-47, Pal. 3050 (juv.)]; three right p3 (Pal. 3044, Pal. 3048-49).

Measurements. - All the measurements are provided in Tabs 1, 2.

Description. - All teeth are rootless.

P2 (Fig. 2A): The sole available P2 in the lagomorph material from 1/2001 is damaged in its buccal part. The tooth shaft is straight and relatively short. The hypercone, lagicone, and postlobus are short, all of similar length. The paraflexus and mesoflexus are well-developed, both are relatively narrow, oriented posteriorly, the latter is longer. The hypercone is rounded, without hypoflexus, and without mesial hyperloph. 


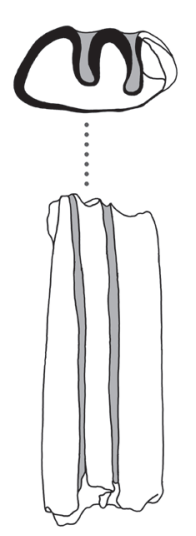

A
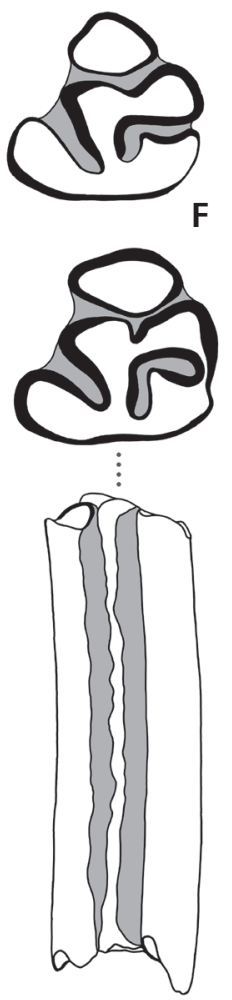
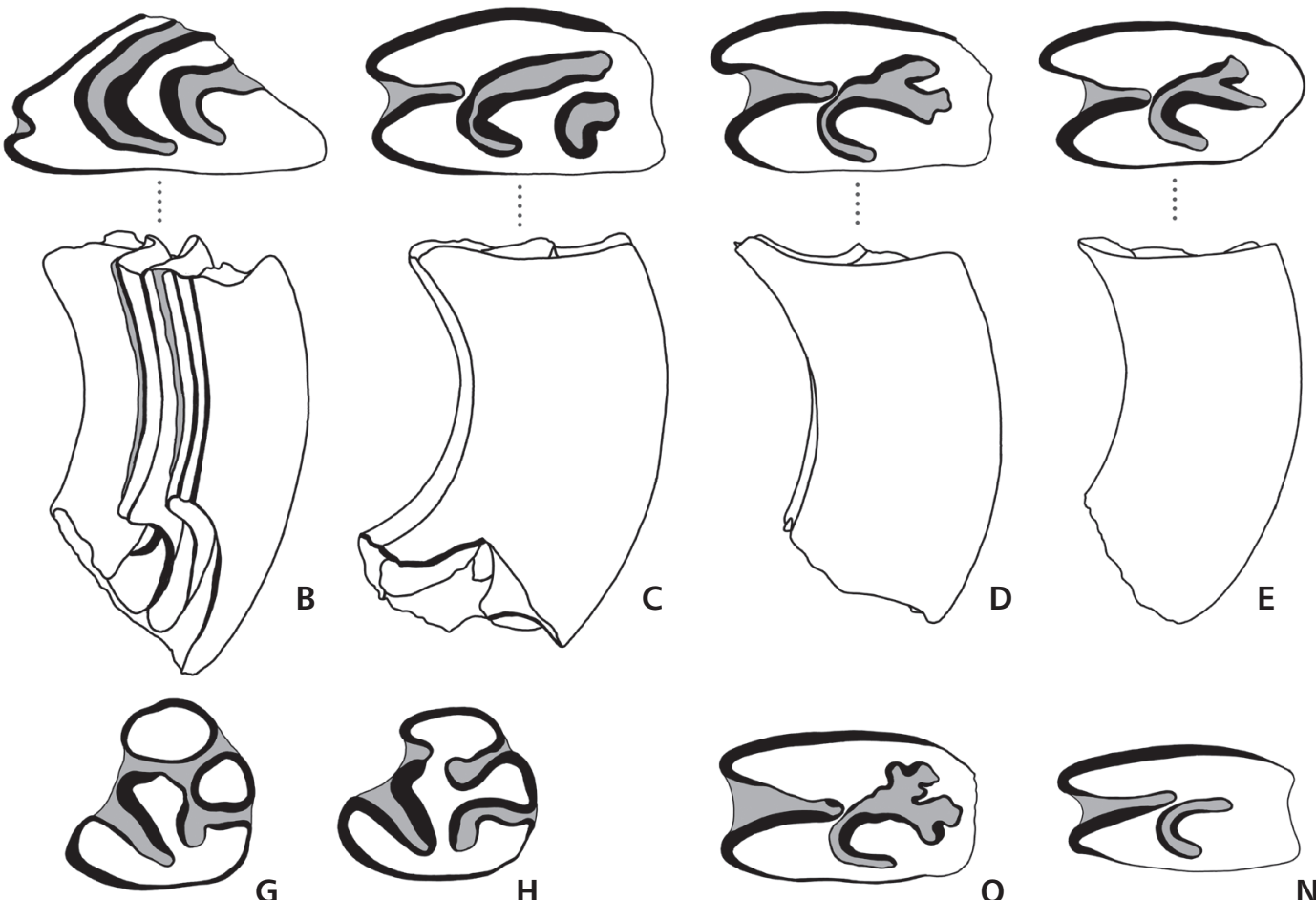

N

Figure 2. Morphology of teeth in Prolagus taxa from MWQ1/2001. A-I, O - Prolagus schnaitheimensis Tobien, 1975; A - left P2 (Pal. 3071), in occlusal and frontal views; B - left P3 (Pal. 3072), in occlusal and frontal views; C - left P4 (Pal. 3083), in occlusal and frontal views; D - left M1 (Pal. 3095), in occlusal and frontal views; E - left M2 (Pal.3104), in occlusal and frontal views; F - left p3 (Pal. 3038), in occlusal view; G - left p3 (Pal. 3039), in occlusal view; H - left p3 (Pal. 3040), in occlusal view; I - left p3 (Pal. 3037), in occlusal and buccal views; O - right M1 (Pal. 3102 ), in occlusal view, reversed. • J-N - Prolagus cf. vasconiensis Viret, 1930 in Roman \& Viret (1930); J - right p3 (Pal. 3115), in occlusal and buccal views, reversed; K - left P3 (Pal. 3117), in occlusal and frontal views; L - left M1 (Pal. 3119), in occlusal and frontal views; M - left M2 (Pal. 3124), in occlusal and frontal views; N - right M1 (Pal. 3123), in occlusal view, reversed. Scale bars $=1 \mathrm{~mm}$; grey for occlusal views, black for frontal and buccal views

P3 (Fig. 2B): The tooth shaft (as with P4-M2) is relatively short with a small radius of linguo-buccal curvature. The lagicone has a simple shape and smooth outline, often with a weak indentation at the base of the lagiloph. The lagiloph is variably developed, from very reduced to long. The postlobus is indented in its anterior side, well developed and extends distinctly on the labial side of the tooth. The distal hypercone is more developed than the mesial one, which is slightly reduced in some cases. The mesial hyperloph is distinctly developed and 
Table 1. Measurements of upper teeth in Prolagus from 1/2001. Abbreviations: AA - partial width; CV - coefficient of variation [\%]; L - length; $\mathrm{Lpl}$ - postlobus length; $\mathrm{M}$ - upper molar; $\mathrm{N}$ - number of specimens; OR - observed range; P - upper premolar; $\mathrm{PH}$ - hypoflexus width; TH - distal hyperloph length; $\mathrm{W}$ - width; Wdh - precone-distal hypercone width; $\overline{\mathrm{x}}$ - arithmetic mean.

\begin{tabular}{|c|c|c|c|c|c|c|c|c|c|}
\hline & & \multicolumn{4}{|c|}{ Prolagus schnaitheimensis } & \multicolumn{4}{|c|}{ Prolagus cf. vasconiensis } \\
\hline & & $\mathrm{N}$ & $\overline{\mathrm{x}}$ & OR & $\mathrm{CV}$ & $\mathrm{N}$ & $\overline{\mathrm{x}}$ & OR & $\mathrm{CV}$ \\
\hline \multirow[t]{4}{*}{ P2 } & $\mathrm{L}$ & 1 & - & 0.80 & - & - & - & - & - \\
\hline & Lpl & 1 & - & 0.70 & - & - & - & - & - \\
\hline & $\mathrm{W}$ & 1 & - & 1.47 & - & - & - & - & - \\
\hline & Wdh & 1 & - & 0.63 & - & - & - & - & - \\
\hline \multirow[t]{4}{*}{ P3 } & $\mathrm{L}$ & 11 & 1.56 & $1.45-1.70$ & 4.88 & 3 & 1.46 & $1.40-1.50$ & - \\
\hline & Lpl & 10 & 0.92 & $0.80-1.00$ & 7.34 & 3 & 0.88 & $0.85-0.90$ & - \\
\hline & W & 11 & 2.61 & $2.45-2.95$ & 5.86 & 3 & 2.18 & $2.15-2.20$ & - \\
\hline & Wdh & 11 & 1.59 & $1.08-2.00$ & 13.60 & 3 & 1.54 & $1.48-1.63$ & - \\
\hline \multirow[t]{5}{*}{ P4 } & $\mathrm{L}$ & 10 & 1.50 & $1.30-1.65$ & 6.22 & - & - & - & - \\
\hline & $\mathrm{TH}$ & 10 & 0.82 & $0.75-0.90$ & 5.78 & - & - & - & - \\
\hline & W & 10 & 2.49 & $2.40-2.60$ & 2.65 & - & - & - & - \\
\hline & AA & 8 & 2.40 & $2.35-2.55$ & 2.97 & - & - & - & - \\
\hline & $\mathrm{PH}$ & 10 & 0.87 & $0.75-1.00$ & 8.65 & - & - & - & - \\
\hline \multirow[t]{4}{*}{ M1 } & $\mathrm{L}$ & 9 & 1.49 & $1.40-1.55$ & 3.53 & 3 & 1.32 & $1.15-1.45$ & - \\
\hline & W & 10 & 2.32 & $2.20-2.58$ & 4.86 & 5 & 2.05 & $1.85-2.25$ & 7.52 \\
\hline & AA & 10 & 2.23 & $2.15-2.48$ & 4.16 & 5 & 1.95 & $1.80-2.10$ & 6.28 \\
\hline & $\mathrm{PH}$ & 9 & 1.08 & $0.93-1.25$ & 8.71 & 5 & 1.26 & $0.95-1.55$ & 20.33 \\
\hline \multirow[t]{4}{*}{ M2 } & $\mathrm{L}$ & 6 & 1.35 & $1.30-1.45$ & 4.14 & 1 & - & 1.23 & - \\
\hline & W & 6 & 2.18 & $2.10-2.25$ & 2.77 & 1 & - & 1.80 & - \\
\hline & AA & 6 & 2.06 & $2.00-2.15$ & 2.63 & 1 & - & 1.70 & - \\
\hline & $\mathrm{PH}$ & 6 & 1.01 & $0.95-1.05$ & 4.35 & 1 & - & 1.40 & - \\
\hline \multirow[t]{4}{*}{ M1/M2 } & $\mathrm{L}$ & 4 & 1.41 & $1.40-1.45$ & 1.78 & - & - & - & - \\
\hline & W & 5 & 2.30 & $2.23-2.38$ & 2.60 & - & - & - & - \\
\hline & AA & 2 & - & $2.15,2.30$ & - & - & - & - & - \\
\hline & $\mathrm{PH}$ & 3 & 0.95 & $0.90-1.00$ & - & - & - & - & - \\
\hline
\end{tabular}

long. The precone does not have enamel hiatus in $91 \%$ of specimens $(\mathrm{N}=11)$. The mesoflexus is of variable depth and curvature, in three cases it is closed into mesofossette. The hypoflexus is shallow and mostly V-shaped.

P4 (Fig. 2C): Two fossettes are present in the tooth. The parafossette is large, wide, and exclusively J-shaped. The buccal end of its anterior (longer) branch is simple in $82 \%$ of specimens $(\mathrm{N}=11)$, in the remaining individuals is bifurcated. In one case only, the anterior branch of parafossette completely covers the mesofossette. The mesofossette is large and very variable in shape, from oval $(27 \% ; \mathrm{N}=11)$ to $\mathrm{L}$-shaped $(27 \%)$ or $\mathrm{C}$ shaped $(36 \%)$. The hypoflexus is short, it reaches an average of about $35 \%$ of tooth width, it is $\mathrm{V}$-shaped in $45 \%$ of specimens $(\mathrm{N}=11)$, in the remaining individuals $\mathrm{V}$-shaped in the lingual edge and $\mathrm{U}$-shaped in the labial one.
M 1 (Fig. 2D, O):Bothteeth,M1 andM2,possessalarge parafossette, whereas the mesofossette is lost. The parafossette in M1 is J-shaped, predominantly $(80 \%, \mathrm{~N}=10)$ with widened and bifurcated buccal end of its anterior (i.e. longer) branch; in two cases this part is distinctly crenulated. The hypoflexus is relatively short, it reaches an average of about $47 \%$ of tooth width; in vast majority $(90 \%, \mathrm{~N}=10)$ it is $\mathrm{V}$-shaped in the lingual edge and U-shaped in the labial one. In one case the hypoflexus is fused with parafossette.

M2 (Fig. 2E): The parafossette is J-shaped. It is less developed than in M1, i.e. shorter and predominantly $(67 \%, \mathrm{~N}=6)$ with widened but simple (not bifurcated) buccal end of its anterior (longer) branch. The hypoflexus is short and of comparable morphology as in M1. It reaches an average of about $46 \%$ of tooth width; in one case the hypoflexus is fused with the parafossette. 
p3 (Fig. 2F-I): Small-sized tooth. Its shaft is straight without antero-posterior bending and, in relation to its occlusal size, relatively short (Fig. 2I). The available material consists of $14 \mathrm{p} 3 \mathrm{~s}$; one of them is a juvenile (shaft with the typical conical appearance), the rest are adults (prismatic shaft). In adult p3s, four basic occlusal patterns were distinguished, with the following combination of features: (i) isolated anteroconid, metaconid connected via metalophid with the protoconid, and occurring mesoflexid ( $46 \%$ of cases; $\mathrm{N}=13$; Fig. $2 \mathrm{~F}$ ); (ii) isolated anteroconid, metaconid connected via metalophid with the protoconid, and occurring mesofossettid ( $31 \%$ of cases; $\mathrm{N}=13$; Fig. 2I); (iii) isolated anteroconid, isolated metaconid, and occurring mesoflexid ( $15 \%$ of cases; $\mathrm{N}=13$; Fig. 2G); (iv) anteroconid connected via anterolophid with the protoconid, metaconid connected via metalophid with the protoconid, and occurring mesoflexid $(8 \%$ of cases; $\mathrm{N}=13$; Fig. $2 \mathrm{H}$ ). In 12 prismatic teeth, the pattern is stable along the entire tooth crown (i.e. the occlusal pattern corresponds to the one in the root side); in one prismatic specimen the occlusal surface has pattern (i), whereas the root side pattern (ii); the same occurs in the sole juvenile specimen of the sample. The occlusal outline is not elongated $(\mathrm{L} / \mathrm{W}=0.96)$. The anteroconid is large, larger than metaconid, predominantly of oval shape, widened antero-lingually. The centroflexid is incipient, very shallow. The protoconid is simple and rounded; the protoflexid and protoconulid are not developed. The protoisthmid is rather wide. The entoconid is quite long, (i.e. longer than $1 / 5$ of tooth length), without enamel hiatus, and often indented in its anterior side. All flexids are smooth without undulation or even crenulation.

Remarks. - Prolagus schnaitheimensis from MWQ1/2001 differs: from P. praevasconiensis Ringeade, 1979 in its larger size, larger $\mathrm{p} 3$ anteroconid, and well-developed $\mathrm{m} 2$ hypoconulid isolated from talonid along the full height of the crown; from P. vasconiensis in its larger occlusal size of the teeth, more straight and relatively shorter $\mathrm{p} 3$ shaft, larger anteroconid of $\mathrm{p} 3$, simpler $\mathrm{p} 3$ protoconid without protoflexid and protoconulid, $\mathrm{P} 3-\mathrm{M} 2$ shafts relatively shorter and with smaller radius of linguo-buccal curvature, larger and more complex fossettes in P4-M2; from P. fortis López-Martínez \& Sesé, 1991 in ÁlvarezSierra et al. (1991) in its more straight and relatively shorter $\mathrm{p} 3$ shaft, larger and wider $\mathrm{p} 3$ anteroconid, simpler p3 protoconid without protoflexid and protoconulid; from P. aguilari López-Martínez, 1997 in its less developed p3 centroflexid, protoflexid, and protoconulid; from Ptychoprolagus forsthartensis Tobien, 1975 in its much less developed enamel crenulation in upper teeth; from P. lopezmartinezae Hordijk \& van der Meulen, 2010a in its larger size of teeth, larger, and wider $\mathrm{p} 3$ anteroconid, simpler $\mathrm{p} 3$ protoconid without protoflexid and protoconulid, simpler P2 hypercone, more developed P3 lagiloph, larger fossettes in $\mathrm{P} 4-\mathrm{M} 2$, shorter hypoflexus

Table 2. Measurements of lower teeth in Prolagus from 1/2001. Abbreviations: CV - coefficient of variation [\%]; L - length; La - anteroconid length; Lme - metaconid-entoconid length; Ltrig - trigonid length; $\mathrm{m}$ - lower molar; $\mathrm{N}$ - number of specimens; OR - observed range; $\mathrm{p}$ - lower premolar; $\mathrm{W}$ - width; Wa - anteroconid width; Wtl - third lobe width of $\mathrm{m} 2$; Wtal - talonid width; Wtrig - trigonid width; $\overline{\mathrm{x}}$ - arithmetic mean.

\begin{tabular}{|c|c|c|c|c|c|c|c|c|c|}
\hline & & \multicolumn{4}{|c|}{ Prolagus schnaitheimensis } & \multicolumn{4}{|c|}{ Prolagus cf. vasconiensis } \\
\hline & & $\mathrm{N}$ & $\overline{\mathrm{x}}$ & OR & $\mathrm{CV}$ & $\mathrm{N}$ & $\overline{\mathrm{x}}$ & OR & $\mathrm{CV}$ \\
\hline \multirow[t]{7}{*}{ p3 } & $\mathrm{L}$ & 12 & 1.71 & $1.63-1.85$ & 4.16 & 1 & - & 1.35 & - \\
\hline & Lme & 13 & 1.22 & $1.13-1.27$ & 3.12 & 1 & - & 0.97 & - \\
\hline & $\mathrm{La}$ & 12 & 0.59 & $0.53-0.67$ & 7.11 & 1 & - & 0.40 & - \\
\hline & W & 12 & 1.77 & $1.63-1.93$ & 4.61 & 1 & - & 1.22 & - \\
\hline & Wa & 12 & 0.92 & $0.75-1.00$ & 9.04 & 1 & - & 0.50 & - \\
\hline & & \multicolumn{8}{|c|}{ Prolagus schnaitheimensis seu $P$. cf. vasconiensis } \\
\hline & & & & $\mathrm{N}$ & $\overline{\mathrm{x}}$ & OR & $\mathrm{CV}$ & & \\
\hline \multirow[t]{4}{*}{$\mathrm{p} 4 / \mathrm{m} 1$} & $\mathrm{~L}$ & & & 14 & 1.11 & $0.93-1.27$ & 10.28 & & \\
\hline & Ltrig & & & 14 & 0.62 & $0.57-0.68$ & 7.24 & & \\
\hline & Wtrig & & & 14 & 1.12 & $1.00-1.25$ & 6.53 & & \\
\hline & Wtal & & & 14 & 1.14 & $0.97-1.30$ & 8.31 & & \\
\hline \multirow[t]{4}{*}{$\mathrm{m} 2$} & $\mathrm{~L}$ & & & 6 & 1.57 & $1.33-1.70$ & 8.63 & & \\
\hline & Wtrig & & & 7 & 1.06 & $0.93-1.17$ & 7.91 & & \\
\hline & Wtal & & & 9 & 1.04 & $0.85-1.15$ & 8.65 & & \\
\hline & Wtl & & & 8 & 0.73 & $0.60-0.87$ & 12.61 & & \\
\hline
\end{tabular}


in M1-M2; from P. oeningensis (König, 1825) in its larger anteroconid of $\mathrm{p} 3$, simpler $\mathrm{p} 3$ protoconid without protoflexid and protoconulid, absence of long centroflexid, larger fossettes in P4-M2, shorter hypoflexus in M1-M2; from $P$. vargasensis Hordijk \& van der Meulen, 2010b in its larger and wider $\mathrm{p} 3$ anteroconid, and presence of protoconid-metaconid connection in $\mathrm{p} 3$.

\section{Prolagus cf. vasconiensis Viret, 1930 in Roman \& Viret (1930)}

Figure 2J-N

Material. - Two left P3 (Pal. 3116-17); one right P3 (Pal. 3118); one left M1 (Pal.3119); four right M1 (Pal.3120-23); one left M2 (Pal. 3124); one right p3 (Pal. 3115).

Measurements. - All the teeth measurements are provided in Tabs 1-2.

Description. - All teeth are rootless.

P3 (Fig. 2K): The tooth shaft is relatively long with a large radius of linguo-buccal curvature. The lagicone has a simple shape and smooth outline. The lagiloph is very reduced. The postlobus is short and does not extend widely on the labial side of the tooth. The pointed distal hypercone is more developed than the rounded mesial one. The mesial hyperloph is distinctly developed and very long. The precone does not have enamel hiatus. The mesoflexus is short and slightly curved. The hypoflexus is shallow and mostly V-shaped.

M1-M2 (Fig. 2L-N): The tooth shafts are relatively long with a large radius of linguo-buccal curvature. The mesofossettes are missing. The parafossettes are small (compared to P. schnaitheimensis) and towards the posterior end of the tooth row are progressively more reduced; from J- to small oval-shaped. The anterior branch of the parafossettes are narrow and simple, without any bifurcation. The length of the hypoflexus is very variable, though it is possible to individuate two distinct variants; (i) four of six teeth have a long hypoflexus reaching about two thirds of W (Fig. 2L-M), (ii) two of six teeth have a relatively short hypoflexus reaching about half of $\mathrm{W}$ (Fig. $2 \mathrm{~N}$ ). The latter variant is associated with a larger and more centrally positioned parafossette (Fig. $2 \mathrm{~N}$ ).

p3 (Fig. 2J): A sole specimen is available in the lagomorph material from MWQ1/2001. The tooth shaft is rootless, prismatic, antero-posteriorly bent, and, in relation to its small occlusal size, relatively long. The occlusal outline is elongated $(\mathrm{L} / \mathrm{W}=1.10)$. The tooth morphology can be assimilated to pattern I (see Remarks of $P$. schnaitheimensis), and it is stable along the entire tooth crown. The anteroconid is diamond-shaped and small, lying in a rather central position with respect to the tooth's antero-posterior axis. The metaconid is small with a size comparable to the anteroconid, and anteriorly concave. The centroflexid is incipient, very shallow. The protoconid is short and rounded, anteriorly with very short protoflexid and incipient protoconulid. The hypoflexid is long, strongly inclined towards the posterior side of tooth. The protoisthmid is rather narrow. The entoconid is quite long, (about a third of the tooth length), without enamel hiatus and with antero-buccal protrusion. The mesoflexid is very long and L-shaped.

Remarks. - Prolagus cf. vasconiensis from MWQ1/2001 differs: from $P$. praevasconiensis in its more complicated p3 protoconid and well-developed $\mathrm{m} 2$ hypoconulid isolated from the talonid along the full height of the crown; from $P$. oeningensis in its smaller size, absence of long p3 centroflexid, reduced P3 lagiloph; from $P$. vargasensis in its smaller size, presence of protoconid-metaconid connection in $\mathrm{p} 3$, shorter P3 lagiloph; from P. fortis in its smaller size, shorter P3 lagiloph; from P. aguilari in its smaller size, smaller and relatively narrower $\mathrm{p} 3$ anteroconid, less developed $\mathrm{p} 3$ centroflexid, protoflexid, and protoconulid; from P. schnaitheimensis in its smaller occlusal size of teeth, relatively longer, and $\mathrm{p} 3$ shaft more curved antero-posteriorly, smaller anteroconid of $\mathrm{p} 3$, more complex $\mathrm{p} 3$ protoconid with incipient protoflexid and protoconulid, relatively longer $\mathrm{P} 3-\mathrm{M} 2$ shafts with larger radius of linguo-buccal curvature, P4-M2 with smaller, narrower, and less developed fossettes; from Ptychoprolagus forsthartensis in its much less developed enamel crenulation in upper teeth. The very scanty material of the taxon under comparison does not show any significant differences in size and morphology of teeth from those found in the central European populations of $P$. vasconiensis and the Iberian species $P$. lopezmartinezae (see "Discussion to the lagomorph material" for justification of the species attribution).

\section{Prolagus schnaitheimensis seu $P$. cf. vasconiensis}

Material. - Seven left p4/m1 (Pal. 3051-55, Pal. 3232-33); seven right $\mathrm{p} 4 / \mathrm{m} 1$ (Pal. 3056-62); three left $\mathrm{m} 2$ [Pal.3063-64 (without trigonid), Pal. 3234]; six right m2 [Pal. 3065-69 (without hypoconulid), Pal. 3070 (without trigonid)].

\section{Measurements. - See Tab. 2.}

Description. - p 4-m 1: Rootless tooth consisting of trigonid and talonid fused together by cement. Both lobes are of similar width and posteriorly have thickened enamel. The trigonid is of rhomboid shape and longer than the talonid. The talonid possesses a variably developed anterior protrusion having an antero-labial flexid and often a shallow anterior notch. 
$\mathrm{m} 2$ : The three-lobed, rootless tooth has the trigonid and talonid similar to those in $\mathrm{p} 4-\mathrm{m} 1$ with the addition of a hypoconulid that is fully developed and isolated from the talonid along the total height of the crown. The hypoconulid is variable in shape, but generally simple and oval.

Remarks. - Lower molariforms do not bear discriminant features allowing a clear distinction between the above described prolagid taxa, therefore, the available material of lower molariforms from MWQ1/2001 is referred here to Prolagus schnaitheimensis seu $P$. cf. vasconiensis.

Order Rodentia Bowdich, 1821

Family Cricetidae Fischer [de Waldheim], 1817

Subfamily Cricetopinae Matthew \& Granger, 1923

Tribe Melissiodontini Schaub, 1925

\section{Genus Melissiodon Schaub, 1920}

\section{Melissiodon dominans Dehm, 1950}

Figure 3A-F

Material and measurements $(L \times W)$. - One left $\mathrm{m} 1$ (Pal. 3005: $2.39 \times 1.9$ ); four left $\mathrm{m} 2$ (Pal. 3000: $2.28 \times 1.79$; Pal. 3002: $2.25 \times 1.75$; Pal. 3003: $2.28 \times 1.79$; Pal. 3004: $2.23 \times 1.68)$; one right $\mathrm{m} 2$ (Pal. 3001: $2.2 \times 1.71)$.
Description. - m1 (Fig. 3A): The anteroconid complex protrudes mesially. A deep well-marked notch isolates both anteroconids. The labial anteroconid shows one posterior spur that connects to a massive anterolophulid cuspid. The lingual anteroconid shows two posterior spurs: one connecting to a mesial spur from the metaconid, likely the metalophulid, and the other one attaching to the anterolophulid cuspid. The labial anterolophulid does not connect to the labial anteroconid, and it shows a small thickening that constitutes the labial anterostylid. The protosinusid is open. The metaconid shows two well-defined spurs running distolingually from it. The protoconid hind arm reaches the most labial spur from the metaconid, which joins with a similar spur running anterolingually from the entoconid, leaving a small sinusid open lingually. The mesostylid is weak but present. The mesoconid is very large. It has a short mesolophid that ends without reaching the mesial spur of the entoconid. The mesoconid is also connected by a short anterior spur to the protoconid hind arm. A well-developed ectolophid connects with the mesoconid. The sinusid is M-shaped and open labially. The posterolophid shows a hypoconulidlike bulge on its most distal side. The entoconid shows two short posterior spurs.

$\mathrm{m} 2$ (Fig. 3B-F): The outline of the teeth is rectangular. From the protoconid departs the anterolophulid,

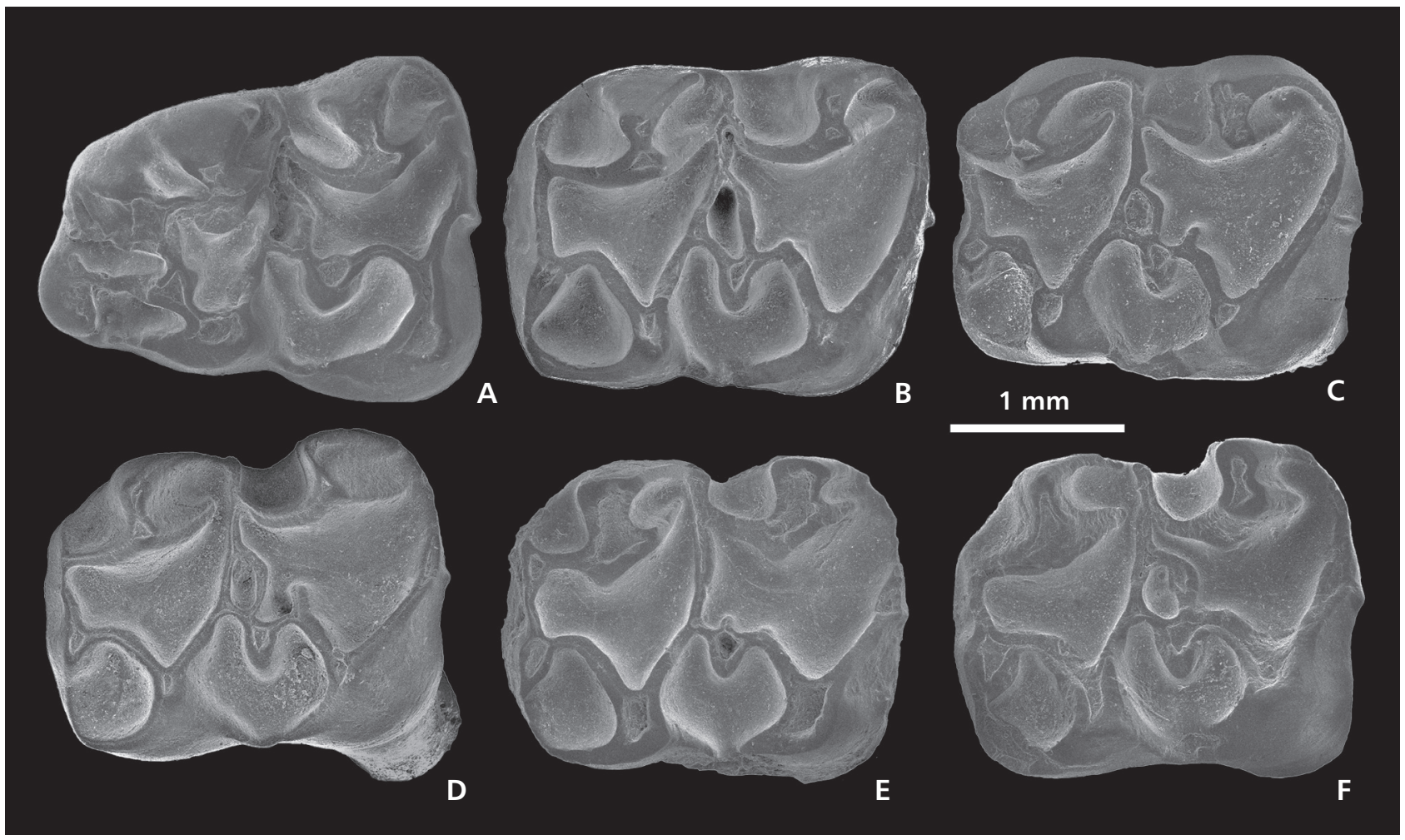

Figure 3. Scanning electron micrographs of Melissiodon dominans Dehm, 1950 from MWQ1/2001 in occlusal view. A - left m1 (Pal. 3005$)$; B - left m2 (Pal.3003); C - left m2 (Pal. 3000); D - left m2 (Pal. 3002); E - left m2 (Pal. 3004); F - right m2, reversed (Pal. 3001). 
longer in Pal. 3002-03, and connects to a well-developed anteroconid. The protosinusid is open. The labial anterolophid connects to the metalophulid. The anterosinusid is open labially. The protoconid hind arm is long and connects with two long spurs departing from the metaconid in Pal. 3003; in the other specimens the more labial spur does not reach the protoconid hind arm. The mesoconid links to the protoconid hind arm. The mesolophid connects to the protoconid hind arm enclosing a very small sinusid, different in each tooth: very short and arched in Pal. 3000 (Fig. 3C); slightly longer and arched in Pal. 3001 (Fig. 3F); and longer enclosing a wider sinusid in Pal. 3002-03. In specimen Pal. 3004 (Fig. 3E), the mesolophid is reduced to a very short spur running lingually from the mesoconid. The sinusid is open labially despite the low cristids running distally from the protoconid and mesially from the hypoconid. There is a hint of a very short hypolophulid in Pal. 3000 and Pal. 3003, and a longer one that does not connect to the entoconid in Pal. 3002. The entoconid shows a well-developed anteriorly directed spur that attaches to the protoconid hind arm, delimiting a small sinusid open labially. The posterolophid is long; in Pal. 3001 shows a thickening that constitutes a distinct hypoconulid. The entoconid presents two short posterior spurs, the lingual one joins the posterolophid.

Remarks. - Melissiodon dominans Dehm, 1950 is a widely studied species known exclusively from Europe ranging from the early Oligocene to the latest early Miocene. During the Miocene, only two Melissiodon species are known: M. schlosseri and M. dominans. Melissiodon arambourgi Crusafont et al., 1955, another Miocene species of the genus described from the Spanish Miocene site of el Fallol, has been recently reviewed by JovellsVaqué \& Casanovas-Vilar (2018) and synonymized with M. dominans. The $\mathrm{m} 1$ from MWQ1/2001 lies within the size variability range of $M$. dominans from all three Dolnice localities and is slightly smaller than the sole tooth measured from Ořechov (Fejfar 1990). Melissiodon dominans from MWQ1/2001 is similar in size to populations of the MN4 of Germany, although the m2 is somewhat narrower than the material from Forsthart (MN4). Moreover, the $\mathrm{m} 1$ fits in the shorter range of the type material from Wintershof-West (MN3; Ziegler \& Fahlbusch 1986), and it is notably smaller than the sole m1 from Maigen, a MN3 Austrian locality (Mein 1989). The $\mathrm{m} 1$ of $M$. dominans from MWQ1/2001 slightly differs from the $\mathrm{m} 1$ material from Maigen, e.g. the mesoconid is weaker and the anterolophid cuspid is absent. Altogether, the ascription of the material to M. dominans is supported by both metrics and morphology, like the two robust anterior cuspids in the $\mathrm{m} 1$ and the reduced mesolophid in the lower molars.
Subfamily Cricetodontinae Schaub, 1925

Genus Megacricetodon Fahlbusch, 1964

\section{Megacricetodon sp.}

Figure 4A, B

Material and measurements $(L \times W)$. - Left maxillary fragment with M1 (Pal. 3013: $1.49 \times 0.93$ ); one fragment of left maxilla with M1 (Pal. 3014: $1.5 \times 0.98)$ and M2 (Pal. 3015: $1.06 \times 0.94$ ).

Description.-M1 (Fig. 4A, B): The anterocone is very large, with a small notch that does not completely divide the cusp into two. There is a small platform in front of the anterocone. A short but thick anterolophule connects the lingual anterocone with the protocone. Both cusps are also linked by a low lingual anteroloph. Pal. 3014 shows a well-marked protostyle, whereas Pal. 3013 (Fig. 4A) only shows a small thickening. The labial anteroloph connects the anterocone with the paracone, showing a very small labial anterostyle, and encloses the anterosinus. The protocone connects with the paracone by means of a very short protolophule. Pal. 3014 shows a very short forward paracone spur that does not connect to a short labial spur of the anterolophule. The mesoloph reaches the labial edge of the tooth in Pal. 3014 (Fig. 4B) and ends close to the base of the metacone in Pal. 3013. There is no distinct mesostyle. A small entostyl is present at the base of the hypocone, much more marked in Pal. 3013. The hypocone is connected to the protocone by a lingual mesocingulum and to the metacone through the posteroloph. The mesosinus is shallow, narrower in Pal. 3014. The posterosinus is narrow and open distally.

M2 (Fig. 4B): The outline of the tooth is rectangular. The lingual cusps are more abraded than the labial ones. The anterosinus is very narrow and there is no protosinus. The protocone is the largest cusp and is connected to the paracone by a short anterior protolophule. Protocone and hypocone are connected by a short entoloph and a low lingual mesocingulum. The sinus is deep and wider than the protosinus. The mesoloph is short and running mesiolabially. The labial mesocingulum is short, with absence of mesostyle. The metalophule runs slightly anteriorly and connects to the hypocone. The distal cusps are also connected by a low posteroloph, which is more developed than in M1s. The posterosinus is wider than in M1s.

Remarks. - The genus Megacricetodon, first defined by Fahlbusch (1964) as a subgenus within Democricetodon, is known in Europe from the early to the late Miocene. Peláez-Campomanes \& Daams (2002) define three different groups of Megacricetodon species, according to their size. The small-sized group, where the available 


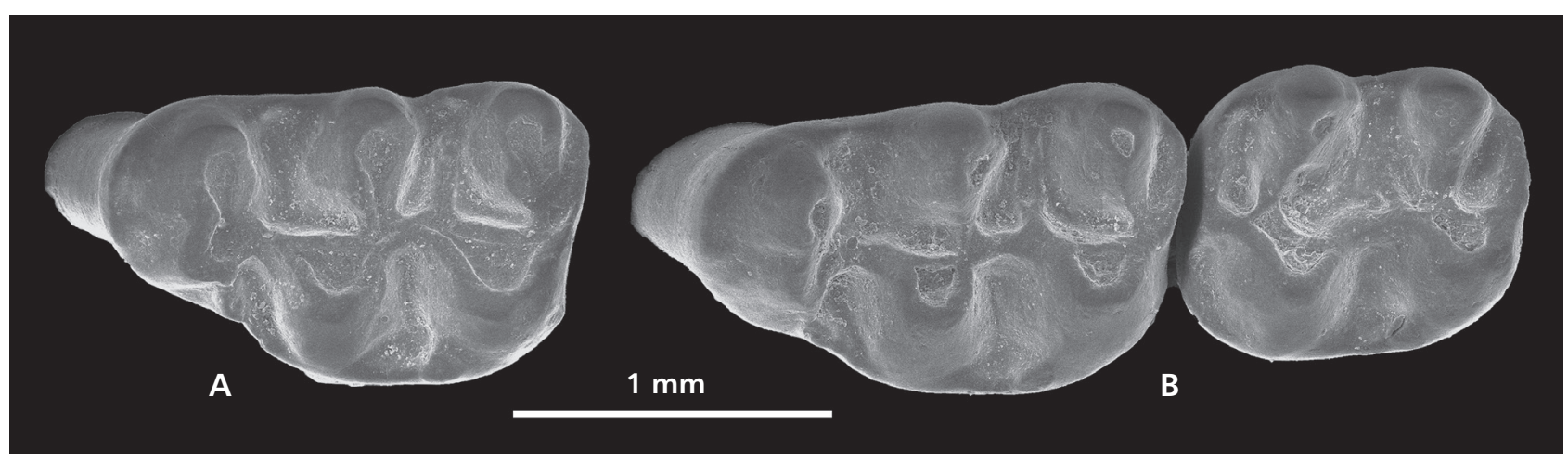

Figure 4. Scanning electron micrographs of Megacricetodon sp. from MWQ1/2001 in occlusal view. A - left M1 (Pal. 3013 ); B - fragment of mandible with left M1 (Pal. 3014) and M2 (Pal. 3015).

material of Megacricetodon sp. from MWQ1/2001 allocates, includes: M. minor Lartet, 1851, M. collongensis Mein, 1958, M. debruijni Freudenthal, 1968, M. primitivus Mein \& Freudenthal, 1971, M. sinensis Qiu et al. 1981, M. pusillus Qiu, 1996, and the recently discovered M. hellenicus Oliver \& Peláez-Campomanes, 2016.

Megacricetodon pusillus and M. sinensis are restricted to Asia, and $M$. debruijni belongs to late Miocene faunas. Furthermore, there is no record of M. minor in MN4 faunas, as it appears in MN5 Central European assemblages, such as in Apistobel $520 \mathrm{~m}$ and Mühlbach (Swiss and Austrian sites, respectively). Kälin \& Kempf (2009) also mentioned a very small new species of Megacricetodon from Apistobel $520 \mathrm{~m}$ and older MN5 localities, which may belong to the same lineage of M. minor. Therefore, the Megacricetodon from MWQ 1/2001 compares with $M$. primitivus, $M$. collongensis and M. hellenicus.

The two M1 from MWQ1/2001 fit well within the dimensional range of $M$. hellenicus from Aliveri North and Aliveri South (Fig. 5), and the M2 is somewhat smaller than the sole M2 recovered from Aliveri North. Despite the similarity in size, there are some differences that prevent the assignation of the material from MWQ1/2001 to $M$. hellenicus, such as the not so well divided anterocone in M1, the presence of a small cingulum in front of the anterocone surrounding it, and the short mesoloph and straight entoloph in M2. The material from MWQ1/2001 also fits well within the range of the small Megacricetodon from Antonios (Vasileiadou \& Koufos 2005), but it differs from the latter in the not completely divided anterocone, the less developed anterior cingulum, the shorter anterolophule, the less developed paracone spur in the M1, and the short mesoloph in the M2.

Megacricetodon sp. from MWQ1/2001 differs from M. primitivus from western European localities for the absence of a completely split anterocone in M1, and the absence of a strong mesocingulum running along the hypocone to the anterocone. Several lineages of this genus have been proposed by Oliver \& PeláezCampomanes (2014, p. 953), with a strong geographic component. According to Oliver \& Peláez-Campomanes (2016), three different lineages are proposed based on three different migration events. The first one corresponds to the appearance of the small-sized $M$. hellenicus from Aliveri (earliest MN4), evolving as an endemic Greek form. The second dispersal event involves the M. bavaricus Fahlbusch, 1964 group, found in different Central European basins. Although the localities Dolnice 3 and Ořechov are similar to Aliveri in age (Fejfar 1990), the Czech Megacricetodon cannot be assigned to the Greek species due to its larger size and different dental morphology. The third dispersal event involves M. primitivus, so far restricted to southwestern Europe. According to Oliver \& Peláez-Campomanes (2016), the M. bavaricus group has the earliest representatives from the Czech assemblages such as Ořechov and Dolnice 3, which are related to the small-sized $M$. aff. collongensis (Swiss and German forms), and M. bezianensis from France. The material from MWQ1/2001 is situated slightly below the size range of $M$. aff. collongensis from Langenau 1 (Fig. 5), but it fits on the lowest range of the samples from Forsthart and Rauscherod, all of them MN4 localities from Germany. Compared with the other Czech assemblages, Megacricetodon sp. from MWQ1/2001 is somewhat larger than the sole M2 from Ořechov, but its morphology shows some clear differences: the presence of mesostyle and posterior spur running from the protocone, and the longer protolophule in the specimen from Ořechov (see Fejfar 1974, fig. 29, nr. 21). Both M1 and M2 from Dolnice 3 are noticeably larger than the material from Mokrá-Quarry locality (Fig. 5), moreover there are some marked differences between both assemblages: the completely split anterocone and a paracone spur running distally that connects to the mesoloph, which are present in the material from Dolnice 3.

The scarce material from MWQ1/2001 is noticeably smaller than the rest of assemblages from the Czech 


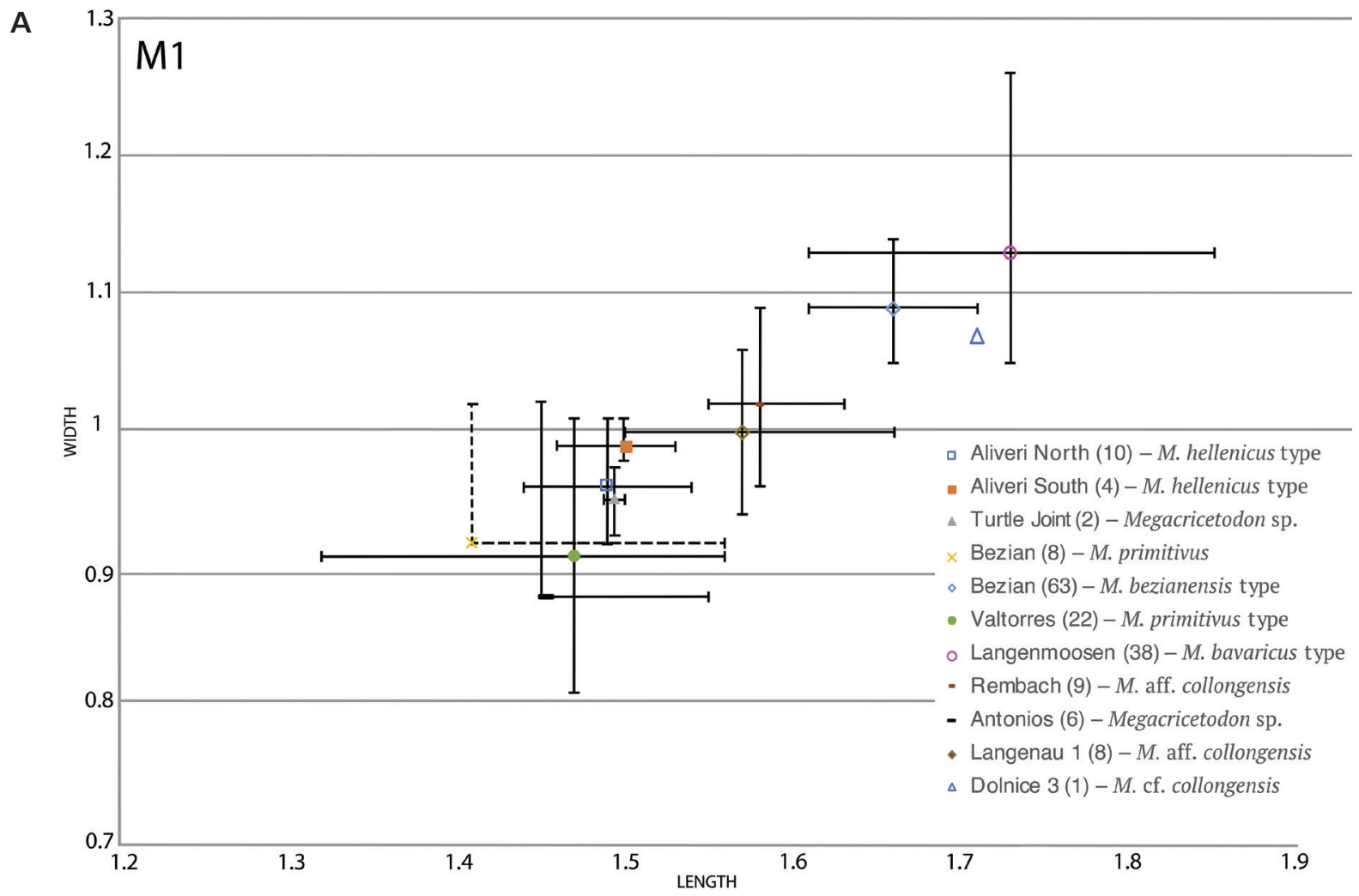

B

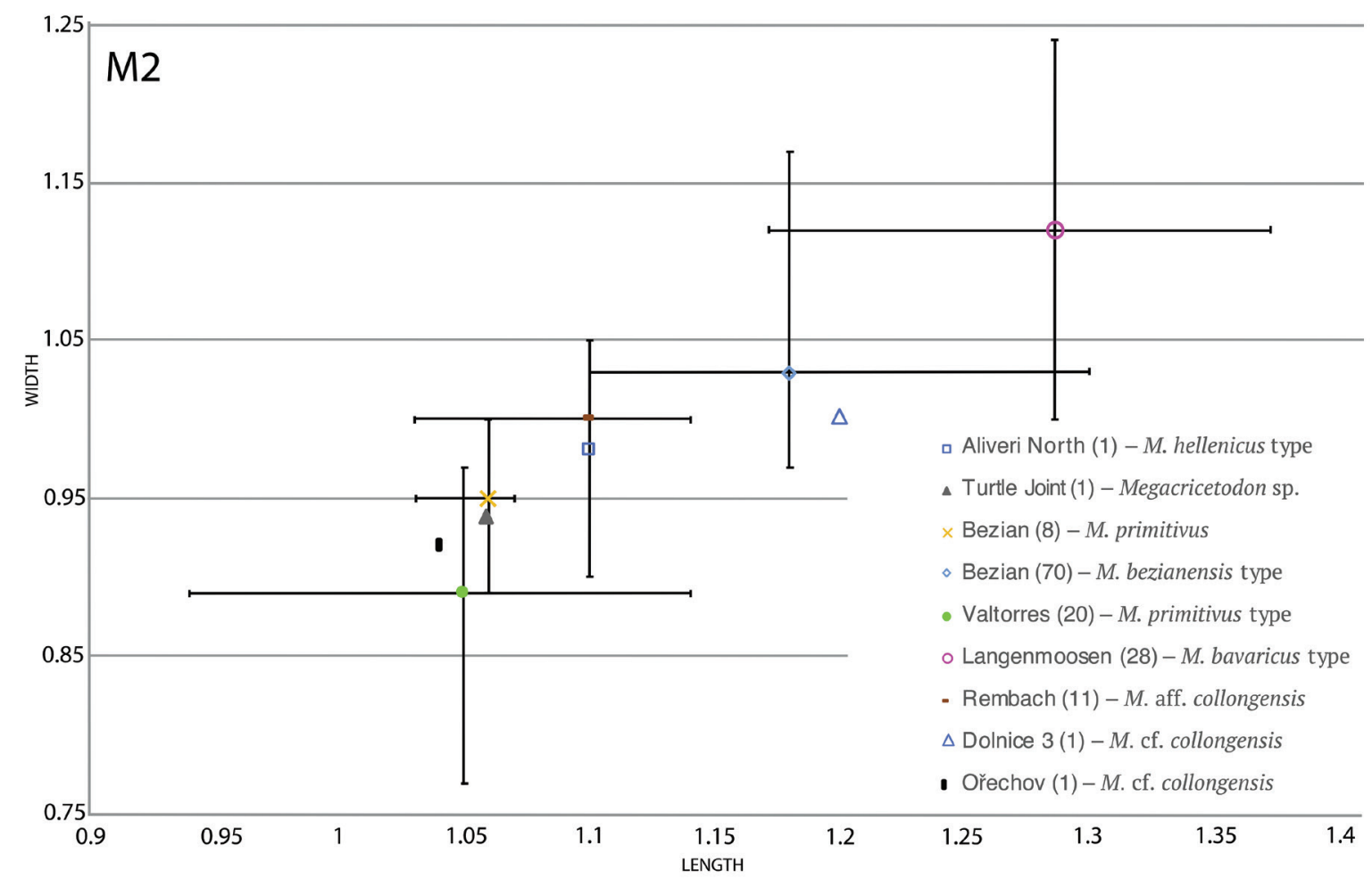

Figure 5. Scatterplot (length and width) of first and second upper molars of several species of Megacricetodon from various localities; A - upper M1; B - upper M2. Type locality and number of specimens is indicated next to locality and species name. In the upper M1, the localities of Antonios and Bezian (M. primitivus) show the full range of length and width, but the means are not represented. Measurements of Megacricetodon species were obtained from the following publications (Fahlbusch 1964, Fejfar 1974, Bulot 1980, Ziegler \& Fahlbusch 1986, Vasileiadou \& Koufos 2005, Oliver \& Peláez-Campomanes 2014, Oliver \& Peláez-Campomanes 2016; Volker J.S. unpublished data). 
Republic and other Central European localities (Fig. 5), all of them referred to the $M$. bavaricus group (PeláezCampomanes \& Daams 2002). The Megacricetodon material from the rest of fissures from Mokrá-Quarry is still under study by one of the authors (I. BonillaSalomón) and will help elucidate the phylogeny of the group as well as its different dispersal events during the early Miocene of Central Europe. Basing on all the above stated information, we decided to tentatively attribute the scarce material from MWQ1/2001 to Megacricetodon sp.

Family Sciuridae Fischer [de Waldheim], 1817

Subfamily Pteromyinae Brandt, 1855

\section{Genus Aliveria de Bruijn, van der Meulen, \& Katsikatsos, 1980}

\author{
Aliveria aff. luteyni de Bruijn, van der Meulen, \& \\ Katsikatsos, 1980 \\ Figure 6A-F
}

Material and measurements $(L \times W)$. - One left P4 (Pal. 3009: $1.75 \times 1.87$ ); two left M1 (Pal. 3010: $1.78 \times$ 2.02; Pal. 3008: $1.84 \times 2.18$ ); one right M1 (Pal. 3006: $1.74 \times 2.02)$; one right M2 (Pal. 3007: $1.9 \times 2.15)$; one left m1 (Pal. 3011: $1.76 \times 1.95$ ); one left m3 (Pal. 3012: $2.19 \times 1.98)$.
Description. - P4 (Fig. 6A): The outline of the tooth is triangular. The parastyle is well-developed; a very low anteroloph runs from it, connecting to the base of the protocone. Protoloph and metaloph converge towards the protocone. The protoconule is much smaller than the metaconule, which is massive. The metaloph is lingually constricted. The mesostyle is small and isolated from the labial cusps. The hypocone is very reduced, integrated into the posteroloph.

M1 (Fig. 6A-C): The protocone is very large, and from it runs a thin and long anteroloph (except in Pal. 3010, in which it is thicker), which reaches the base of the paracone without connecting to it. Both cusps are connected through the protoloph, which thickens into a protoconule in Pal. 3008. The mesostyle is well-developed and isolated from the labial cusps. The metaloph runs towards the protocone, with an especially thick and elongated metaconule in Pal. 3006 (Fig. 6B). A short endoloph connects the protocone with a not so well-developed hypocone. The posteroloph is low, leaving the sinus open.

M2 (Fig. 6D): The outline of the tooth is square. There is no parastyle. Protocone and paracone are connected through a low anteroloph and a well-developed protoloph. There is a thickening on the latter that could constitute a distinct protoconule. There is a worn but distinct mesostyle attached to the paracone. The metaloph runs mesiolingually to the protocone and shows a well-

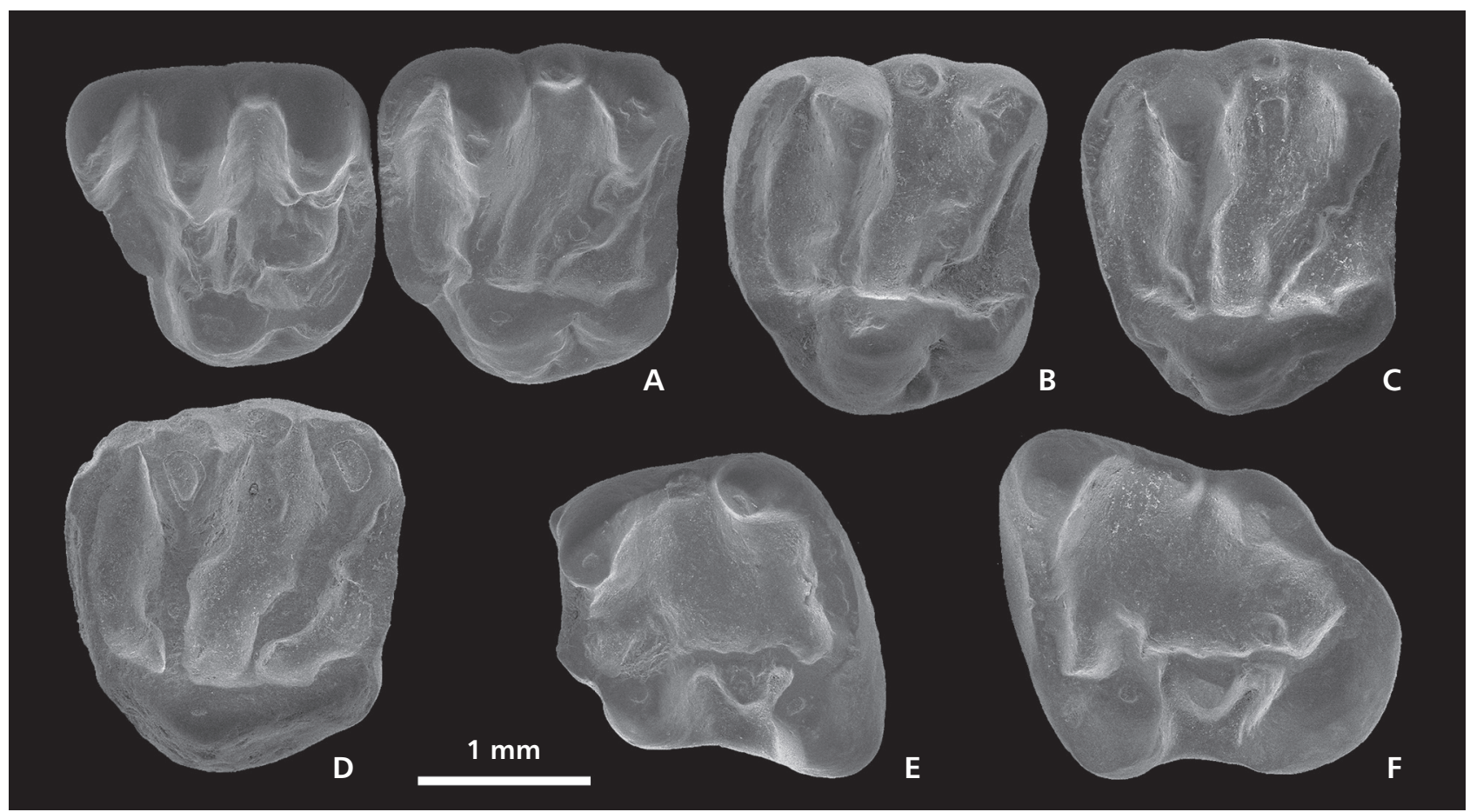

Figure 6. Scanning electron micrographs of Aliveria aff. luteyni de Bruijn, van der Meulen, \& Katsikatsos, 1980 from MWQ1/2001 in occlusal view; A - fragment of left maxilla with P4 (Pal. 3014) and M1 (Pal. 3015); B - right M1, reversed (Pal. 3006); C - left M1 (Pal. 3008); D - right M2, reversed (Pal. 3007); E - left m1 (Pal.3011); F - left m3 (Pal. 3012). 
developed and single metaconule. The hypocone is reduced, only constitutes a small bulge fused with the endoloph that connects to the protocone. The posteroloph runs very low, leaving the sinus open.

$\mathrm{m} 1$ (Fig. 6E): The protoconid is round, large and attached to a well-developed anteroconulid, which is also connected to the base of the metaconid by a short anterolophid. Metaconid and protoconid are also connected by a very low and weak metalophid. There is a small but distinct mesostylid, attached to the metaconid and isolated from the entoconid by a well-marked notch. The ectolophid is low and continuous, connecting the two labial cuspids and enclosing the central valley. There is a massive mesoconid. The hypoconid is well-developed although abraded. From it a well-developed posterolophid connects with the entoconid, which is the smallest cuspid. The entolophid is absent. The posterolophid is higher on its lingual side.

$\mathrm{m} 3$ (Fig. 6F): This tooth is slightly longer than $\mathrm{m} 1$, with a more rounded distal side. The enamel is slightly crenulated. The protoconid shows a short spur running lingually from it. The anterolophid is high and connects to the metaconid. There is no anteroconid. There is a small but distinct mesostylid, connected to the metaconid but isolated from the entoconid by a pronounced notch. The ectolophid connects both labial cuspids and shows a welldeveloped mesoconid. The hypoconid is massive and connects to the entoconid by a well-developed and thick posterolophid.

Remarks. - Aliveria de Bruijn, van der Meulen, \& Katsikatsos, 1980 is a genus of medium-sized flying squirrels, described from the locality of Aliveri. Two different species have been described so far from the type locality: A. luteyni and $A$. brinkerinki. Both species differ mainly in size, the latter being larger (de Bruijn et al. 1980). Aliveria has been mostly recorded in several sites from the Anatolian region and Balkan area (Doukas 2003, Bosma et al. 2019) but remains outside this area are scarce. Besides the type locality it has only been found out of the Anatolian region in Sibnica (Marković et al. 2016). The sciurid material recovered from MWQ1/2001, formerly attributed to Palaeosciurus sp. (Sabol et al. 2007) is ascribed to the genus Aliveria based on the presence of a well-delimited hypocone in M1-2, the convergence of protoloph and metaloph towards the protocone, and the presence of a well-developed anteroconid in the lower molars. The sciurid remains from MWQ1/2001 fit within the size range of A. luteyni from Aliveri and it is clearly smaller than $A$. brinkerinki from the same locality. It is also somewhat larger than the material from Sibnica 4 assigned to Aliveri aff. luteyni by Marković et al. (2016). It shows closer affinity to $A$. luteyni, like the $\mathrm{m} 3$ morphology from Klapangi 1 (Bosma et al. 2019, fig. 7d) and the reduced hypocone in M1-2, despite several features are markedly different. The material from MWQ1/2001 differs from A. luteyni from Aliveri in the presence of a very large parastyle on the P4; an elongated metaconule in M1-2, instead of double like in the specimens from the type locality; a well-marked mesostyle, isolated from the paracone in the upper molars; a more rounded protocone; absence of a complete metalophid on m1-2. Despite the similar size of the material from MWQ1/2001 with Aliveria luteyni, the morphological differences stated above prevents the assignation of these sciurid remains to this species. However, the scarcity of the remains recovered from MWQ1/2001 prevents the erection of a new species. For that reason, it is assigned to Aliveria aff. luteyni.

Order Erinaceomorpha Gregory, 1910

Family Erinaceidae Fischer [de Waldheim], 1817

Subfamily Galericinae Pomel, 1848

\section{Genus Galerix Pomel, 1848}

\section{Galerix sp.}

Figure 7A-D

Material and measurements $(L \times W)$. - One right M2 (Pal. 3016: $2.13 \times 2.69$ ); one fragment of left M2 (Pal. 3017); two left m2 (Pal. 3018: $2.56 \times 1.56$; Pal. 3019: $2.72 \times 1.65$ ).

Description. - M2 (Fig. 7 A, B): The crown is only slightly worn, almost undamaged in Pal. 3016. In Pal. 3017 (Fig. 7B) only the distal half is preserved. There is a very small preparacrista running mesiolabially from the paracone, but here is no distinct parastyle. The postparacrista joins the premetacrista; a mesostyle is absent. It has a U-shaped postmetacrista running to the distobuccal corner of the tooth. At the end of it there is a small worn metastyle, which is almost unnoticeable in Pal. 3017. At the base of the metacone there is a thin crest that connects it to a large and round metaconule. The protocone is large; the preprotocrista running from it does not connect to the base of the paracone. The trigon basin enclosed is deep. The hypocone connects through the prehypocrista to the postprotocrista. There is a well-marked concavity on the lingual outline of the tooth, between the lingual cusps. Both mesial and distal cingula are well-developed.

$\mathrm{m} 2$ (Fig. 7C, D): The crown is slightly worn. The lingual cuspids are somewhat higher than the labial ones. The paraconid is completely merged into the paralophid in Pal. 3019 (Fig. 7D) and only constitutes a small bulge in Pal. 3018. The paralophid is round and runs from the protoconid towards the base of the metaconid but without reaching it. In Pal. 3019, the protoconid and metaconid are also connected by a strong protolophid that links to 


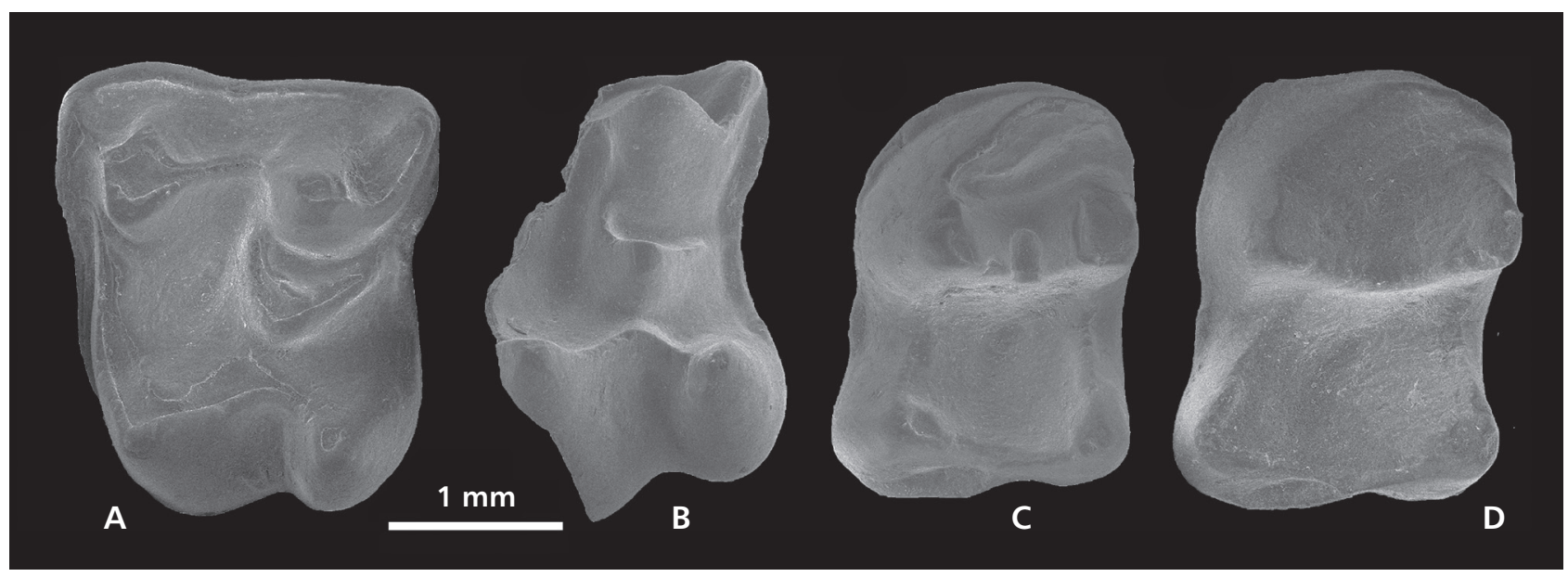

Figure 7. Scanning electron micrographs of Galerix sp. from MWQ1/2001 in occlusal view; A - right M2, reversed (Pal. 3016); B - fragment of left M2 (Pal. 3017); C - left m2 (Pal. 3018); D - left m2 (Pal. 3019).

the metalophid. There is no metacristid. The postcristid connecting the hypoconid with the entoconid is much lower in Pal. 3019.

Remarks. - The clearly wider than longer M2 morphology, together with the crescent shape of the metaconule, is indicative of the tribe Galericini, which is very common in the Miocene of Europe. The genus Galerix is characterized by the posterior arm of the metaconule not reaching the posterolabial side of the tooth, feature that is clearly present in the material from MWQ1/2001. During the early Miocene, two species of Galerix are present in Central Europe: G. symeonidisi Doukas, 1986 and G. aurelianensis Ziegler, 1990. The sole complete M2 from MWQ1/2001 is clearly smaller than that of G. aurelianensis from Erkertshofen 2 and Petersbuch 2, whereas the two $\mathrm{m} 2$ fit on the smaller range of the sample from the above-mentioned localities (Ziegler 1990). Compared with the sole $\mathrm{m} 2$ recovered from the Czech site of Ahníkov/Merkur north Mine (MN3), the sample from MWQ1/2001 is somewhat narrower (see van den Hoek Ostende \& Fejfar 2006). Besides the size differences, G. aurelianensis usually has a connection between the protocone and the metaconule (Ziegler 1990), which is absent in the M2 and fragment of M2 from MWQ1/2001. Compared with G. symeonidisi from other Central European localities, the M2 from MWQ1/2001 is larger than the material from Erkertshofen 2, in fact, it fits in the upper size range of the material from Erkertshofen 1 and in the lower size range of the specimens from Petersbuch 2 (Ziegler \& Fahlbusch 1986). The M2 is similar in size to the specimens of $G$. symeonidisi from the late early Miocene localities from Germany, e.g. Fortshart, Rembach and Rauscheröd (Ziegler \& Fahlbusch 1986). Both $\mathrm{m} 2 \mathrm{~s}$ are larger than those from the above-mentioned German late early Miocene sites. In spite of the above recognized morphological and dimensional similarities with $G$. symeonidisi, for a precise attribution of the Galerix remains at the species level, the morphology of the upper and lower premolars has to be taken into account. Given that those teeth are missing in the assemblage from MWQ1/2001, the material is here referred to Galerix sp.

Order Chiroptera Blumenbach, 1779

Family Rhinolophidae Gray, 1825

\section{Genus Rhinolophus Lacépède, 1799}

\section{Rhinolophus cf. cluzeli Hugueney, 1965}

Figure 8A-C

Material and measurements. - Left humerus [Pal. 3036: 3.70 (width of epiphysis), 1.43 (width of epicondyle), 1.53 (capitulum width), 1.3 (width of diaphysis)]; left mandible with (p3-root), p4 (Pal. 3035: L $1.36 \times \mathrm{W}$ 1.03), m1 (Pal. 3844: L2.05 × Wtr 1.4, Wtl 1.45), and m2 (Pal. 3845: L 2.06× Wtr 1.35, Wtl 1.43).

Description. - Humerus (Fig. 8A): The preserved portion of the humerus (distal epiphysis) shows all the characters of large-sized horseshoe bats: broad medial epicondyle with processus spinosus (that is broken in Pal. 3036); sharp medial margin of trochlea; and broad capitulum extending to a cylindric lateral epicondyle. Compared to $R$. delphinensis from Devínska Nová Ves, the lateral epicondyle is relatively narrow, but its diameter is close to the one of the capitulum, while its lateral fossa is deeper with a slit-like proximal opening (as in R. kowalskii).

Mandibular fragment (Fig. 8B, C): Minute p3 (root) is displaced at labial margin of $\mathrm{p} 4$, molariform dentition is robust, molars are nyctalodont with sharp entoconid crests. 
p4 (Fig. 8B, C): the base of the tooth is rectangular. The cuspid is pyramidal in shape, sharply pointed and separated by vertical distal wall from spacious distal cingular basin with conspicuous incision in its labial base. Both posterior and lingual faces are roughly concave. A cingulid surrounds the base of the tooth, which is thicker on its distal side.

$\mathrm{m} 1$ (Fig. 8B, C): The tooth is only slightly worn. The protoconid is massive, being the highest cuspid; it connects to the paraconid and a distinct low staying paracristid through a narrower preprotocristid. Correspondingly, a thicker postprotocristid connects protoconid to the metaconid and a short but thick metacristid. The precingulid is wide and connects to the postcingulid by means of a welldeveloped labial cingulid. The entoconid is thinner than the other cuspids and links to the base of the metaconid through a preentocristid that runs along the lingual margin of the tooth. The hypoconid is very large but lower than the protoconid, and it is connected to it by a straight crista obliqua. From the hypoconid runs a sharp postcristid that attaches to a small hypoconulid.

$\mathrm{m} 2$ (Fig. 8B-C): The tooth is nearly unworn. The protoconid is thicker than the $\mathrm{m} 1$ while the trigonidal fossid is somewhat narrower than in $\mathrm{m} 1$. The cingulid runs continuously from the anterior part of the tooth to the hypoconulid. The entoconid is small and attaches to the base of the metaconid through the sharp preentocristid. The crista obliqua connects the hypoconid with the distolingual side of the base of the protoconid. The postcristid is even sharper than in $\mathrm{m} 1$ while hypoconulid is somewhat less distinct.

Remarks. - In Miocene karstic sites, rhinolophids are often the only component of the bat fossil record (Ziegler 1993, 2003). Typically, this clade is represented there with a large-sized form resembling the extant Rhinolophus ferrumequinum. As a rule, it is coidentified with $R$. delphinensis Gaillard, 1899 from the MN7+8 site of La Grive. This species was reported from at least 15 Miocene sites (MN3-MN13). Besides, two other species of the same size category were distinguished: $R$. lemanensis Revilliod, 1920 (type locality MN2, Saint-Gérand-le-Puy) reported also from Winterhof-West and three other sites of MN3-MN4 age (Ziegler 1993); and R. cluzeli Hugueney, 1965 from Coderet-Branssat (MP30) and VieuxCollonges (MN4: as R. aff. delphinensis in Mein 1958). Both these forms differ from $R$. delphinensis by a lesser degree of premolar reduction and a slenderer form of p4 with a sharply pointed main cuspid and an enlarged distal cingulid basin with ventral flexion of its labial base. Rhinolophus lemanensis is somewhat larger than $R$. delphinensis and $R$. cluzeli appears at the lower range of $R$. delphinensis metric variation. We directly compared the specimen from MWQ1/2001 with $R$. delphinensis from several Miocene sites, including the specimens from its type locality (La Grive) and with $R$. cluzeli from Vieux-Collonges (both kindly provided to IH by Pierre Mein). Significant differences have been found in the shape of $\mathrm{p} 4$ between the mandibles from MWQ1/2001 and $R$. delphinensis, but a there is instead a good match between the mandibles from MWQ1/2001 and R. cluzeli. The morphology of the humerus of $R$. aff. lemanensis from Wintershof-West figured by Ziegler (Ziegler 1993, pl. 3.3), is almost identical with Pal. 3036 from Mokrá MWQ1/2001, particularly as concerns its heavily build lateral epicondyle, yet dimensions of the latter are much smaller $(\mathrm{W}=3.70 \mathrm{~cm}$ in Pal. $3036 v s .4 .86-5.68 \mathrm{~cm}$ in Wintershof-West).

\section{Rhinolophus cf. grivensis (Depéret, 1892)}

Figure 8D-F

Material and measurements. - Right mandible with $\mathrm{m} 2$ (Pal. 3033: L 1.34 × Wtr 0.74, Wtl 0.89) and m3 (Pal. 3846: L $1.31 \times$ Wtr 0.87 , Wtl 0.89 ); toothless fragment mandible (Pal. 3034).

Description. - Both mandibles show nearly identical alveolar configuration: a very large rounded alveolus of p2; relatively large alveolus of $\mathrm{p} 3$ not compressed and occupying a labial half of toothrow between $\mathrm{p} 2$ and $\mathrm{p} 4$; relatively long p4; and equal size of all molars. The teeth in mandible Pal. 3033 (Fig. 8D-F) are strongly worn, nyctalodont, with distinct entoconid crests and indistinct hypoconulids connected by a straight postcristids to massive hypoconids. Trigonids on both teeth are relatively narrow, with straight mesial walls. Compared to the high and pointed metaconids, the paraconids are much less distinct. The base of trigonidal fossid is low and marked by a distinct basal cingulid. The protoconid is the highest cuspid and connects to the paraconid and the metaconid through the protocristid and a thick metacristid and thinner paracristid. The cristid obliqua connecting the hypoconids with the distal base of protoconids are straight, without any undulation. Hypoconids are heavily worn. In both teeth, the talonids are noticeably broader and larger in square than the trigonids. In contrast to the extant species of $R$. euryale, $R$. hipposideros or $R$. lepidus groups, the $\mathrm{m} 3$ of the specimens Pal. 3033 shows almost no trace of reduction, except for a slight medial shift in position of its entoconid.

Remarks. - The small-sized representative of the genus in the present sample. is tentatively attributed to $R$. grivensis (including similis Zapfe, 1950), the species reported from 13 Miocene (MN3-MN10) sites. Both the two specimens from Mokrá show distinctly smaller dimensions than R. dehmi Ziegler, 1993 from Wintershof- 


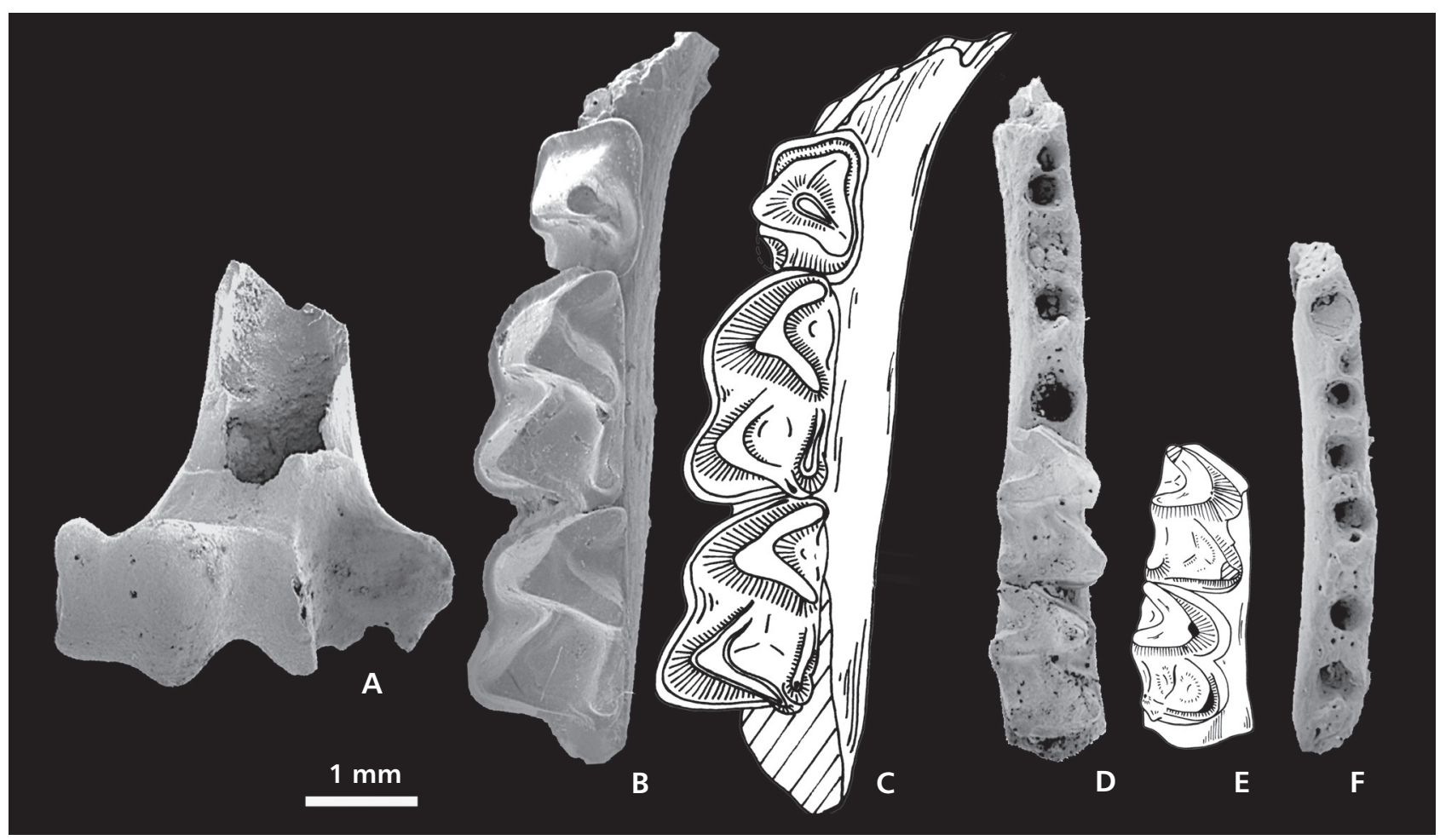

Figure 8. A, C-scanning electron micrographs and drawings of Rhinolophus cf. cluzeli Hugueney, 1965 from MWQ1/2001 in occlusal view; A - left humerus (Pal. 3036); B, C - left mandible with (p3), p4 (Pal. 3035), m1 (Pal. 3844) and m2 (Pal. 3845). D, F - scanning electron micrographs and drawings of Rhinolophus cf. grivensis from MWQ1/2001 in occlusal view; D, E - right mandible with $\mathrm{m} 2$ (Pal.3033) and m3 (Pal. 3846 ); F - toothless fragment mandible (Pal. 3034).

West but fall in the dimensional range of $R$. grivensis as reported for populations of several early to middle Miocene sites by Ziegler (2003). The low degree of $\mathrm{m} 3$ reduction conspicuous in our specimen and supporting the suggested identification is also worth of mentioning in these connections.

Anyhow, the actual taxonomic identity of the Miocene representatives of the genus (including the large-sized forms mentioned above) is in no way a trivial problem. Regarding an excessive phylogenetic diversity of extant rhinolophids in tropic and subtropic habitats, we may expect a large number of species also in the Neogene European fossil record, similarly as multiple cases of parallel morphoclines, and quite minute phenotypic differences among individual species. The detailed analyses of large population samples are required to resolve these questions.

\section{Discussion}

\section{Biostratigraphic considerations}

The early Miocene continental fossil record of the Czech Republic is quite well-documented. To date, there are two well-known MN3 localities: Tuchořice and Ahníkov/
Merkur Mine. Regarding the MN4, there are three levels of Dolnice, while in South Moravia Region two localities are reported: Ořechov and Mokrá-Quarry. On the preliminary study devoted to small mammals from MWQ1/2001 by Sabol et al. (2007), the MN4 age for this karst fissure was proposed. It was based mainly on the co-occurrence of the genera Melissiodon (its last occurrence is at the end of MN4) and Megacricetodon, which first appears in Central Europe during the MN4. In addition, the small-mammal assemblage was correlated with other early Miocene Czech localities such as Dolnice 3 and Ořechov, both MN4b in age, based on the small mammal assemblage (Fejfar 1990). Dolnice 3 and Ořechov have yielded scarce remains of Megacricetodon; this genus is absent in Dolnice 1 and 2. The mammalian fossiliferous sequence of Ořechov is located below the Oncophora (Rzehakia) beds, which limits the boundary between Ottnangian and Karpatian stages (Cicha et al. 1972). It has close affinities to the assemblage of Dolnice 3, especially for the presence of Megacricetodon. The similar age for both Czech sites was also supported by Ziegler \& Fahlbusch (1986), when comparing the MN4b localities from Germany (Rembach, Fortshart and Rauscheröd) to both Ořechov and Dolnice localities. Moreover, these authors also confirmed that the upper limit of the Oncophora beds marked the boundary between the Ottnangian and Karpatian stages. The other 
two Dolnice assemblages ( 1 and 2), which yielded remains of Democricetodon, Ligerimys antiquus and L. florancei, lack remains of the rodent genus Megacricetodon (Fejfar 1990). Therefore, both assemblages were referred to a somewhat older age (MN4a: see van der Meulen et al. 2011).

Kälin \& Kempf (2009) define the Democricetodon franconicus-Megacricetodon collongensis interval zone, with Glovelier as the reference locality, in the Northern Alpine Foreland Basin of Switzerland. This local mammal zone is characterized by the first occurrence of the modern cricetid Democricetodon, and the genus Ligerimys, being the latter represented by L. antiquus and L. florancei. It is noteworthy that the top of this mammal zone is marked by the first appearance datum (FAD) of Megacricetodon. Based on the absence of Megacricetodon, Dolnice 1 and 2 were dated older than Ořechov and Dolnice 3, in agreement with the work of van der Meulen et al. (2011). Furthermore, the above-mentioned biozone was placed between $17.55 \mathrm{Ma}$ and $17.15 \mathrm{Ma}$. This age agrees with the one proposed for Dolnice 3 and Orrechov, which remain in the late MN4.

However, works focusing on the stratigraphy of Swiss and German Molasse Basins have yielded different results regarding the correlation with the age and $\mathrm{MN}$ zonation of the Czech localities. Research conducted on the stratigraphy of the Upper Freshwater Molasse in western Bavaria propose an older age for the Czech locality of Ořechov (Abdul Aziz et al. 2010). The authors pointed out that the Oncophora beds, which overlain the Ořechov section, are correlated to the Kirchberg Formation (Brackish Water Molasse), and therefore, they assume a middle-late Ottnangian age (around $18 \mathrm{Ma}$ : MN4a) for Ořechov. Considering this information, Ořechov marks the FAD of Megacricetodon in Central Europe; the size of Megacricetodon from Ořechov is smaller than that from Langenau, a locality recording the earliest appearance of this genus in the North Alpine Foreland Basin (NAFB), correlative to the base of the Kirchberg Formation, and therefore slightly younger than Ořechov. An age of about $18 \mathrm{Ma}$ for both Ořechov and Dolnice 3 would make the localities of Dolnice 1 and 2 even older. On the other hand, other studies did not support the age for Ořechov given on the latter study (see Kälin \& Kempf 2009, van der Meulen et al. 2011). According to these studies, the presence of Ligerimys antiquus, Melissiodon and the first record of Democricetodon define Spanish Zone A, which ends around $17 \mathrm{Ma}$. Furthermore, this faunal association can be correlated with other localities from Central Europe such as Glovelier (Switzerland), Petersbuch 2 and Erkersthofen 1 and 2 (Germany), Dolnice 1 and 2 (Czech Republic), and Oberdorf 3 and 4 (Austria). Given that Dolnice 3 and Ořechov reported Megacricetodon remains, they should be considered the youngest sites.
Nevertheless, the German locality Achen 17 did not support the age of Ořechov proposed by Abdul Aziz et al. (2010), which is on the strontium content of otoliths. In fact, Achen 17 shows a similar assemblage to the faunas registered from Dolnice 1 and 2, where Democricetodon and Pseudotheridomys are common, and Megacricetodon is missing. Considering that the site was dated around $17.8 \pm 0.3 \mathrm{Ma}$, it would make the $18 \mathrm{Ma}$ date for Ořechov unsustainable, considering the faunal differences between both assemblages.

Recently, Reichenbacher et al. (2013) presented a new magnetostratigraphic and biostratigraphic correlation of the Swiss and South German Molasse Basins. This work proposed a new Ottnangian-Karpatian boundary, pushing the limit of these two stages half a million years younger. Thus, the Kirchberg Formation and the age of the Oncophora beds were reconsidered, being the new correlation aged between 17.2 and 17.3 Ma. Consequently, the age of Ořechov, located below the Oncophora beds, was dated around 17.3 Ma. Since Dolnice 3 shows an assemblage very similar to Ořechov, an alike age for it is expected. Moreover, the latest studies focusing on Megacricetodon from Central European localities (Fejfar 1990, Abdul Aziz et al. 2010, Oliver \& Peláez-Campomanes 2016) agree with the latest proposal by Reichenbacher et al. (2013), placing Dolnice 3 and Ořechov on the early MN4, and consider these remains to be the first representatives of the M. bavaricus group (Oliver \& Peláez-Campomanes 2016).

\section{The age of MWQ1/2001 Turtle Joint}

In general terms, the composition of faunal assemblage from MWQ1/2001 is similar to the other early Miocene Czech localities. Our results presented here confirm an early Miocene age (MN4) for this locality based on the composition of the small mammal assemblage (see Systematic palaeontology above), as tentatively stated by previous works. The final allocation of MWQ1/2001 within the MN4 zone (early or late) remains to be specified. It is remarkable that the scarce Megacricetodon material recovered from MWQ1/2001 is significantly different from those from Ořechov and Dolnice localities (see remarks of Megacricetodon sp. above), in both size and morphology. Despite this, the alpha taxonomy of the remains from MWQ1/2001 together with the evolutionary history and different dispersals of Megacricetodon in Central Europe is still uncertain. Although there is a temporal trend in size increase along the different lineages of Megacricetodon (Abdul Aziz et al. 2010, fig. 3), further research on the early evolution of the genus is required. The smaller size of the remains from MWQ1/2001 compared to those from Dolnice 3 and Ořechov (and even smaller than $M$. aff. 
collongensis from Langenau 1) could agree with an older age of the fossil assemblage. Besides, the Megacricetodon from MWQ1/2001 shows clear morphological differences with the species from Aliveri but resembles it in size. This could represent the earliest dispersal of this genus into Central Europe from Asia. The study of additional remains of Megacricetodon, as well as the genus Ligerimys (of great biostratigraphical value) in the rest of fissures will be very useful to elucidate the correct allocation of MokráQuarry localities in the early Miocene.

\section{Palaeoecology}

As stated in the Systematic Palaeontology section, the small mammal assemblage recovered from MWQ1/2001 is relatively diverse. To date, eight different taxa have been recovered: two lagomorphs; two chiropterans; one hedgehog; and three rodents. Over $75 \%$ of that assemblage belongs to remains of Lagomorpha. The early Miocene prolagids from Central Europe can be regarded as forest-dwellers or as a peri-aquatic/riparian-dwellers, although their presence in more open-forest areas cannot be excluded ( $c f$. López-Martínez 2001). The genus Aliveria belongs to the flying squirrel group. Flying squirrels, which lived in forest environments, are in general characterized by its nocturnal activity (de Bruijn 1999). The record of Melissiodon is indicative of the presence of wooden areas and somewhat humid conditions according to Jovells-Vaqué \& Casanovas-Vilar (2018), although its feeding behaviour is still under discussion. Mein \& Freudenthal (1981) suggest a frugivorous diet for this genus, whereas Agustí \& Antón (2002) advocate for an arboreal behaviour and a diet based on leaves. However, recent works (Wessels et al. 2018) suggested that the specialization of the morphology of the chewing apparatus of the Melissiodontinae is rather an adaptation to feeding on small invertebrates. As for Megacricetodon, given its opportunistic condition, habitat preferences are still uncertain. In any case, as a ground dweller genus it could indicate open-forest conditions (Kälin 1999).

Regarding the rhinolophid bats, they are strict cavedwellers foraging invertebrates in foliage (Storch 1999). This is consistent with a forest or semi-opened karstic vegetation. The presence of these bats indicates a spacious cave in time of deposition, close to these forest and semiopen karstic vegetation. Ziegler (1999) pointed out that the close relatives of Galerix live in forested environments, close to water bodies, where they feed on invertebrates, frogs and some plant matter. However, other works point out that Miocene Galericini, such as Galerix and Parasorex, were adapted to a high diversity of habitats (GarcíaAlix et al. 2008; Furió et al. 2011, 2018); these taxa were event present in Miocene assemblages typical of arid conditions (Minwer-Barakat et al. 2009, Furió et al. 2011). At any rate, the presence of the erinaceids in MWQ1/2001 agrees with semi-open karstic vegetation surrounded by water bodies. The large mammal association is still under study by one of the authors of the present work (I. Bonilla-Salomón) and mainly consists of cervids and one suid. Although they require forest biotopes, it cannot be excluded that they could have lived close to a swampy environment (Rössner 2004). Essentially, the mammal assemblages from MWQ1/2001 indicate warm weather conditions with patches of open forest and open steppe with the presence of marshy areas, which is typical of karst landscapes.

Palaeoecological reconstruction based on the study of small mammals reinforces the results obtained by the study of other vertebrate groups i.e. amphibians and reptiles. The diverse community of peri- or semi-aquatic amphibians (Chelotriton, Triturus, Bufo and Pelophylax; Ivanov 2008) and reptiles (Ptychogaster, Natrix, Colubrinae; Alba et al. 2018; Ivanov et al. 2018, 2020; Luján et al. 2014, in press) in MWQ1/2001 indicates the presence of damp and marshy habitats with stagnant or slow flowing waters in the locality. The absence of crocodilians and most of freshwater turtle genera (i.e. Trionyx, Rafetus, Clemmydopsis, Mauremys, Chelydropsis) at MWQ1/2001 suggest the presence of shallow and non-permanent water masses (Díaz Aráez et al. 2017, Luján et al. 2019). Some water reservoirs were most probably surrounded by sandy shores with welldrained substrates as documented by the occurrence of the extinct pelobatid frog Pelobates sanchizi (Venczel 2004, Böhme \& Vasilyan 2014). Species well-adapted to more humid terrestrial environments have been also reported, such as Chelotriton sp., whose adults probably inhabited damp habitats with dense vegetation (Estes 1981, Ivanov 2008). Similarly, Pseudopus laurillardi inhabited humid woodland environments. However, diverse assemblage of terrestrial heliophilic squamates [e.g. Ophisaurus, Varanus mokrensis, Bavarioboa cf. hermi, Vipera ('Oriental vipers' group)] and a testudinid (Testudo cf. kalksburgensis; Luján et al. 2016, 2017) show on the open woodland, bushes and grassland in close vicinity of water reservoirs. The presence of thermophilic taxa in MWQ1/2001 including Python, Varanus, Bavarioboa, as well as elapids and 'Oriental vipers' indicate rather warm climatic conditions during the Miocene Climatic Optimum with mean annual temperatures reaching at least $18-19^{\circ} \mathrm{C}$ (Ivanov et al. 2018, 2020).

\section{Conclusions}

The small mammal remains from the early Miocene locality of MWQ1/2001 (Mokrá-Western Quarry, South 
Moravia, Czech Republic) are described and attributed to eight taxa: Prolagus schnaitheimensis, P. cf. vasconinensis, Melissiodon dominans, Megacricetodon sp., Aliveria aff. luteyni, Galerix sp., Rhinolophus cf. cluzeli, R. cf. grivensis. The faunal assemblage corresponds to the MN4, based on one of the last occurrences of Melissiodon together with the presence of the cricetid Megacricetodon. MWQ1/2001 shows a micromammal assemblage similar to those of Dolnice 3 and Ořechov. Although scarce, the remains of Megacricetodon sp. from MWQ1/2001 are essential to the understanding the appearance and different migration waves of this genus in Europe. More remains from the unpublished Mokrá-Quarry localities, especially from $2 / 2003$, which has also yielded remains of Megacricetodon will provide new insights on the early evolution of the first immigrants of this Asian genus. The presence of some open-forest dwellers like Megacricetodon, together with more forested habitants like Melissiodon, Aliveria and Galerix, agree with the paleoenvironmental reconstruction of MWQ1/2001 as an open karst landscape, surrounded by water bodies and patches of forest.

\section{Acknowledgements}

The research reported in this work has been supported by: the VEGA Scientific Agency (M.S., I.B.S.: 1/0164/19); the APVV grant agency of the Slovak Republic (M.S., I.B.S.: APVV16-0121); the UK grant of the Comenius University (I.B.S. UK/56/2019 and UK/100/2020); SČ by the RVO67985831 of the Institute of Geology of the Czech Academy of Sciences; a specific research project at the Faculty of Science at Masaryk University, Brno (MI); the Spanish Agencia Estatal de Investigación (CGL2016-76431-P, CGL2017-82654-P and AEI/ FEDER-UE to À.H.L.) the Generalitat de Catalunya (CERCA Program); and the Operational Programme Research, Development and Education - Project "Postdoc@MUNI" (No. CZ.02. 2.69/0.0/0.0/16_027/0008360 to À.H.L).We thank Jan Wagner, handling editor, as well as Chiara Angelone and Raef MinwerBarakat for their constructive comments that greatly improved the article.

\section{References}

AbdulAziz, H., Böhme, M., Rocholl, A., Prieto, J., Wijbrans, J.R., Bachtadse, V. \& Ulbig, A. 2010. Integrated stratigraphy and ${ }^{40} \mathrm{Ar} /{ }^{39} \mathrm{Ar}$ chronology of the early to middle Miocene Upper Freshwater Molasse in western Bavaria (Germany). International Journal of Earth Sciences 99, 1859-1886. DOI 10.1007/s00531-009-0475-8

Agustí, J. \& Antón, M. 2002. Mammoths, Sabertooths, and Hominids. 313 pp. Columbia University Press, New York. Alba, D.M., Casanovas-Vilar, I., Furió, M., García-Paredes, I.,
Angelone, C., Jovells-Vaqué, S., Luján, À.H., Almécija, S. \& MoyÀ-SolÀ, S. 2018. Can Pallars i Llobateres: A new hominoid-bearing locality from the late Miocene of the Vallès-Penedès Basin (NE Iberian Peninsula). Journal of Human Evolution 121, 193-203.

DOI 10.1016/j.jhevol.2018.04.008

Álvarez-Sierra, M.A., Daams, R., Lacomba, J.I., LopezMartinez, N., van der Meulen, A.J., Sese, C. \& De Visser, J. 1991. Palaeontology and biostratigraphy (micromammals) of the continental Oligocene-Miocene deposits of the North-Central Ebro Basin (Huesca, Spain). Scripta Geologica 94, 1-77.

Angelone, C. \& Sesé, C. 2009. New characters for species discrimination within the genus Prolagus (Ochotonidae, Lagomorpha, Mammalia). Journal of Paleontology 83(1), 80-88. DOI 10.1666/07-067R2.1

BlumenBACH, J.F. 1779. Handbuch der Naturgeschichte. 448 pp. J.C.D., Göttingen.

Böhme, M. \& Vasylan, D. 2014. Ectothermic vertebrates from the late Middle Miocene of Gratkorn (Austria, Styria). Palaeodiversity and Palaeonvironments 94, 21-40.

DOI 10.1007/s12549-013-0143-7

Boon-Kristkoiz, E. \& KristKoiz, A.R. 1999. Order Lagomorpha, 259-262. In Rössner, G. \& Heissig, K. (eds) The Miocene Land Mammals of Europe. Verlag Dr. Friedrich Pfeil, Munich.

Bosma, A.A., Bruijn, H. DE \& Wessels, W. 2019. Early and middle Miocene Sciuridae (Mammalia, Rodentia) from Anatolia, Turkey. Journal of Vertebrate Paleontology 38(6), 1-25. DOI 10.1080/02724634.2018.1537281

Bowdich, T.E. 1821. An Analysis of the Natural Classifications of Mammalia for the use of students and travelers. $115 \mathrm{pp}$. J. Smith, Paris.

BRAnd, J.F. 1855. Beiträge zur nähern Kenntniss der Säugethiere Russlands. Mémoires de l'Académie impériale des sciences de St. Pétersbourg 7, 1-365.

Bruijn, H. DE 1999. Superfamily Sciuroidea, 271-280. In Rössner, G.E. \& Heissig, K. (eds) The Miocene Land Mammals of Europe. Verlag Dr. Friedrich Pfeil, Munich.

Bruijn, H. de, van der Meulen, A.J. \& Katsikatsos, G. 1980. The Mammals from the Lower Miocene of Aliveri (lsland of Evia, Greece) Part 1. The Sciuridae. Proceedings B 83(3), 241-261.

Brzoвohatý, R. 1997. Paleobatymetrie spodního badenu karpatské předhlubně na Moravě z pohledu otolitových faun, 37-45. In Hladilová, Š. (ed.) Dynamika vztahů marinniho a kontinentálního prostředi. Masaryk Univeristy, Brno.

Brzobohatý, R., KudĚLÁseK, V. \& Nehyba, S. 2000. Nejspodnější baden (střední miocén) v okolí Mokré u Brna. Geologické výzkumy na Moravě a ve Slezsku 7, 58-60.

Bulot, C. 1980. Nouvell description de deux espèces du genre Megacricetodon (Cricetidae, Rodentia) du Miocène de Bézian (one de La Romieu). Bulletin du Muséum national d'histoire naturelle, Section C Sciences de la terre, paléontologie, géologie, minéralogie 2(1), 3-16.

Cicha, I., Fahlbusch, V. \& Fejfar, O. 1972. Die biostratigraphische Korrelation einiger jungtertiärer Wirbeltierfaunen Mitteleuropas. Neues Jahrbuch für Geologie und Paläontologie, Abhandlungen 140(2), 129-145. 
Crusafont, M., Villalta, J.F. De \& Truyols, J. 1955. El Burdigaliense continental de la cuenca del Vallés-Penedés. $M e-$ morias y Comunicaciones del Instituto Geológico 12, 1-247.

Cuenca-Bescós, G. 1988. Revisión de los Sciuridae del Aragoniense y del Rambliense en la fosa de CalatayudMontalbán. Scripta Geologica 87, 1-116.

Denм, R. 1950. Die Nagetiere aus dem Mittel-Miocän (Burdigalium) von Wintershof-West bei Eichstätt in Bayern. Neues Jahrbuch für Geologie und Paläontologie, Abhandlungen 91, 321-428.

Depéret, C. 1892. Sur la faune d'Oiseaux pliocènes du Roussillon. Mémoires de la Société géologique de France. Paleontologie 3, 127-139.

Díaz Aráez, J.L., Delfino, M., Luján, À.H., Fortuny, J., Bernardini, F. \& Alba, D.M. 2017. New remains of Diplocynodon (Crocodylia: Diplocynodontidae) from the early Miocene of the Iberian Peninsula. Comptes Rendus Palevol 16(1), 12-26. DOI 10.1016/j.crpv.2015.11.003

DoukAS, C.S. 1986. The mammals from the Lower Miocene of Aliveri (Island of Evia, Greece). Part 5. The insectivores. Proceedings of the Koninklijke Nederlandse Akademie van Wetenschappen B 89(1), 15-38.

Doukas, C.S. 2003. The MN4 faunas of Aliveri and Karydia (Greece), 127-132. In López-Martínez, N., Peláez-CAMPOmanes, P. \& Hernández Fernández, M. (eds) En torno a fósiles de mamíferos: datación, evolución y paleoambiente. Coloquios de Paleontología, Volumen Extraordinario 1.

EngEsser, B. 1980. Insectivora und Chiroptera (Mammalia) aus dem Neogen der Türkei. Schweizerische Paläontologische Abhandlungen 102, 49-150.

Ekrt, B., Mikuláš, R., Wagner, J., Čermák, S., Procházková, K., Kadlecová, E. \& FeJfar, O. 2016. New contribution to the palaeoichnology and taphonomy of the Ahníkov fossil site, Early Miocene, Most Basin (the Czech Republic). Fossil Imprint 72(3-4), 202-214. DOI 10.14446/FI.2016.202

Estes, R. 1981. Gymmophiona. Caudata, 1-115. In Wellnhofer, P. (ed.) Handbuch der Paläoherpetologie. Munich.

Fahlbusch, V. 1964. Die Cricetiden (Mamm.) der Oberen Süßwasser-Molasse Bayerns. Bayerische Akademie der Wissenschaften, Mathematisch-Naturwissenschaftliche Klasse, Abhandlungen, Neue Folge 118, 1-136.

FeJfar, O. 1974. Die Eomyiden und Cricetiden (Rodentia, Mammalia) des Miozäns der Tschechoslowakei. Palaeontographica Abteilung A 146, 100-180.

FeJfar, O. 1990. The Neogen VP sites of Czechoslovakia: A contribution to the Neogen Terrestric Biostratigrapphy of Europe Based on Rodents, 211-236. In LindsaY, E.H., Fahlbusch, V. \& Mein, P. (eds) European Neogene Mammal Chronology. Plenum Press, New York. DOI 10.1007/978-1-4899-2513-8_15

Fejfar, O. \& HorÁČeK, I. 1983. Zur Entwicklung der Kleinsäugerfaunen im Villanyium und Alt-Biharium auf dem Gebiet der ČSSR. Schriftenreihe für Geologische Wissenschaften 19-20, 111-208.

FeJfar, O. \& KvaČEK, Z. 1993. Excursion Nr. 3, Tertiary basins in North-west Bohemia. 35 pp. Universita Karlova and Česká geologická společnost, Prague.
Fejfar, O. \& RočEK, Z. 1986. The Lower Miocene Vertebrate Fauna of Dolnice, Cheb Basin (Western Bohemia, Czechoslovakia). Acta Universitatis Carolinae, Geologica 2, 233-249.

Fejfar, O., Dvořák, Z. \& Kadlecová, E. 2003. New record of Early Miocene (MN3a) mammals in the open brown coal pit Merkur, North Bohemia, Czech Republic, 163-182. In Reumer, J.W.F. \& Wessels, W. (eds) Distribution and Migration of Tertiary mammals in Eurasia. A Volume in Honour of Hans de Bruijn. Deinsea 10.

Fischer [De Waldheim], G. 1817. Adversaria zoologica. Mémoires de la Société impériale des naturalistes de Moscou 5 , $357-472$.

Freudenthal, M. 1968. On the mammalian fauna of the Hipparion-beds in the Calatayud-Teruel Basin. Part IV: The genus Megacricetodon (Rodentia). Proceedings of the Koninklijke Nederlandse Akademie van Wetenschappen B 71, 57-72.

Furió M., Casanovas-Vilar, I. \& van den Hoek Ostende, L.W. 2011. Predictable structure of Miocene insectivore (Lipotyphla) faunas in Western Europe along a latitudinal gradient. Palaeogeography, Palaeoclimatology, Palaeoecology 304(3-4), 219-229.

DOI 10.1016/j.palaeo.2010.01.039

Furió, M., van den Hoek Ostende, L.W., Agustí, J. \& MinWER-BARAKat, R. 2018. Evolución de las asociaciones de insectívoros (Eulipotyphla, Mammalia) en España y su relación con los cambios climáticos del Neógeno y el Cuaternario. Ecosistemas 27(1), 38-51.

DOI 10.7818/ECOS.1454

Gaillard, C. 1899. Mammifères miocènes nouveaux ou peu connus de la Grive-Saint-Alban (Isère). Archives du Muséum d'Histoire Naturelle de Lyon 7, 1-78.

DOI 10.5962/bhl.title.86383

García-Alix, A., Minwer-Barakat, R., Martín Suárez, E., Freudenthal, M. \& Martín, J.M. 2008. Late Miocene-Early Pliocene climatic evolution of the Granada Basin (southern Spain) deduced from the paleoecology of the micromammal associations. Palaeogeography, Palaeoclimatology, Palaeoecology 265(3-4), 214-225.

DOI 10.1016/j.palaeo.2008.04.005

GrAY, J.E. 1825. An outline of an attempt at the disposition of Mammalia into tribes and families, with a list of the genera apparently appertaining to each tribe. Annals of Philosophy 10, 337-344.

Gregory, W.K. 1910. The orders of mammals. Bulletin of the American Museum of Natural History 27, 1-524.

Gureev, A.A. 1960. Lagomorphs (Lagomorpha) from the Oligocene of Mongolia and Kazakhstan. Trudy Instituta Paleontologii Akademija Nauk SSSR 77, 5-34. [in Russian]

Hand, S. 1985. New Miocene Megadermatids (Chiroptera, Megadermatidae) from Australia with comments on Megadermatid Phylogenetics. Australian Mammalogy 8(1-2), $5-44$.

Hilgen, F.J., Lourens, L.J. \& VAn Dam, J.A. 2012. The Neogene period, 923-978. In Gradstein, F.M., OGG, J.G., Schmitz, M. \& OGG, G. (eds) The Geologic Time Scale 2012. Elsevier, Amsterdam. DOI 10.1016/B978-0-444-59425-9.00029-9 
Hladil, J., Bernardová, E., Brunnerová, Z., Brbzobohatý, R., Čekan, V., Dvořák, J., Eliáš, M., Friáková, O., Havlíček, P., Kalvoda, J., Klečák, J., Machatková, B., Maštera, L., Mittrenga, P., Otava, J., PřIchystal, A., ReJl, L. \& RŮžIČKa, M. 1987. Vysvětlivky k základni geologické mapě České republiky 1:25 000 list Mokrá-Horákov. Archive of the Czech Geological Survey. Prague.

HorÁČEK, I. \& ŠpoutIL, F. 2012. Why tribosphenic? On variation and constraints in developmental dynamics of chiropteran molars, 410-455. In Gunnell, G.F. \& Simmons, N.B. (eds) Evolutionary History of Bats. Fossils, Molecules and Morphology. Cambridge University Press, Cambridge. DOI $10.1017 / \mathrm{CBO} 9781139045599.013$

HordiJk, K. \& van der Meulen, A.J. 2010a. Systematics of resident species of Lagopsis and Prolagus (Ochotonidae, Lagomorpha, Mammalia) from the late early and middle Miocene of northeastern Central Spain, 17-85. In HordiJK, K. Perseverance of pikas in the Miocene. Interplay of climate and competition in the evolution of Spanish Ochotonidae (Lagopmorpha, Mammalia). Ph.D. thesis, Utrecht University.

Hordijk, K. \& van der Meulen, A.J. 2010b. Systematics of immigrant species of Prolagus (Ochotonidae, Lagomorpha, Mammalia) from the late early and middle Miocene of northeastern Central Spain, 87-141. In HoRDIJK, K. Perseverance of pikas in the Miocene. Interplay of climate and competition in the evolution of Spanish Ochotonidae (Lagopmorpha, Mammalia). Ph.D. thesis, Utrecht University.

Hordijk, K., Duijnstee, I.A.P. \& van der Meulen, A.J. 2010. Speciation, evolution and competition in pikas (Ochotonidae, Lagomorpha, Mammalia) from the early and middle Miocene of Southwestern Europe, 143-173. In HordiJK, K. Perseverance of pikas in the Miocene. Interplay of climate and competition in the evolution of Spanish Ochotonidae (Lagopmorpha, Mammalia). Ph.D. thesis, Utrecht University.

Hordij,, K., Bosma, A., Bruijn, H. De, van Dam, J., Geraedts, C., van den Hoek Ostende, L.W., Reumer, J. \& Wessels, W. 2015. Biostratigraphical and palaeoecological implications of the small mammal assemblage from the late early Miocene of Montalvos 2, Teruel Basin, Spain. Palaeobiodiversity and Palaeoenvironments 95(3), 321-346.

DOI 10.1007/s12549-015-0203-2

Hugueney, M. 1965. Les Chiroptères du Stampien supérieur de Coderet-Branssat (Allier). Travaux et Documents des Laboratoires de Géologie de Lyon 9(1), 97-127.

Ivanov, M. 2008. Early Miocene Amphibians (Caudata, Salientia) from the Mokrá-Western Quarry (Czech Republic) with comments on the evolution of Early Miocene amphibian assemblages in Central Europe. Geobios 41(4), 465-492. DOI 10.1016/j.geobios.2007.11.004

Ivanov, M. \& Musil, R. 2004. Předběžné výsledky výzkumu neogenních obratlovců z lokality Mokrá-lom. Acta Musei Moraviae Scientiae Geologicae 89, 223-236.

Ivanov, M., Musil, R. \& Brzobohatý, R. 2006. Terrestrial and Marine Faunas from the Miocene Deposits of the Mokrá Plateau (Drahany Upland, Czech Republic) - Impact on Palaeogeography. Beiträge zur Paläontologie 30, 223-239.

Ivanov, M., Ruta, M., Klembara, J. \& Böhme, M. 2018. A new species of Varanus (Anguimorpha: Varanidae) from the early Miocene of the Czech Republic, and its relationships and palaeoecology. Journal of Systematic Palaeontology 16(9), 767-797. DOI 10.1080/14772019.2017.1355338

IVANov, M., ČERŇANSKÝ, A., Bonilla-SAlOMÓN, I. \& LuJÁn, À.H. 2020. Early Miocene squamate assemblage from the Mokrá-Western Quarry (Czech Republic) and its palaeobiogeographical and palaeoenvironmental implications. Geodiversitas 42(20), 343-376.

DOI 10.5252/geodiversitas2020v42a20

Jovells-Vaqué, S. \& Casanovas-VILAR, I. 2018. A review of the genus Melissiodon (Cricetidae, Rodentia) in the Vallès-Penedès Basin (Catalonia). Journal of Vertebrate Paleontology 38(5), 1-9. DOI 10.1080/02724634.2018.1520714

Kälin, D. 1999. Tribe Cricetini, 373-387. In Rössner, G.E. \& Heissig, K. (eds) The Miocene Land Mammals of Europe. Verlag Dr. Friedrich Pfeil, Munich.

Kälin, D. \& KempF, O. 2009. High-resolution stratigraphy from the continental record of the Middle Miocene Northern Alpine Foreland Basin of Switzerland. Neues Jahrbuch Fur Geologie Und Palaontologie, Abhandlungen 254(1-2), 177-235. DOI 10.1127/0077-7749/2009/0010

KöNIG, C.D.E. 1825. Icones. Fossilium Sectiles: Centuria Prima. 4 pp. G.B. Sowerby, London. DOI 10.5962/bhl.title.60262

LACÉPÈDE, B.G.E. 1799. Mémoire sur une nouvelle table méthodique des animaux à mamelles. Mémoires de l'Institut National des Sciences et des Arts, Sciences Mathématiques et Physiques 3, 469-502.

LARTEt, E. 1851. Notice sur la colline de Sansan, Suivie d'une Récapitulation de Diverses Espèces d'Animaux Vertébrés Fossiles Trouvés soit à Sansan, soit dans d'Autres Gisements du Terrain Tertiaire Miocène dans le Bassin Sous-Pyrénéen. 45 pp. J.-A. Portes, Auch.

Linnaeus, C. 1758. Systema Naturae per regna tria naturae, secundum Classes, ordines, genera, species, cum characteribus, differentiis, synonymis, locis. Tomus 1. Edito decima, reformata. $824 \mathrm{pp}$. Laurentii Salvii, Holmiae.

DOI 10.5962/bhl.title.542

LóPEZ-MARTíneZ, N. 1989. Revisión sistemática y biostratigráfica de los Lagomorpha (Mammalia) del Terciario y Cuaternario de España. Memorias del Museo Paleontologico de la Universidad de Zaragoza 3, 1-342.

López-Martínez, N. 1997. Lignées évolutives, formes intermédiaires et évolution en mosaïque: exemple de lagomophes européens. In Aguilar J.P., Legendre, S. \& Michaux, J. (eds) Actes du Congres BiochroM'97. Mémoires et Travaux de l'Institut de Montpellier de l'Ecole Pratique Hautes Etudes 21, 105-120.

López-Martínez, N. 2001. Paleobiogeographical history of Prolagus, an European ochotonid (Lagomorpha). Lynx 32, 215-231.

Luján, À.H., Delfino, M., Casanovas-Vilar, I. \& Alba, D.M. 2014. Taxonomy of subgenus Temnoclemmys Bergounioux, 1958 (Testudines: Geoemydidae: Ptychogasterinae) based on new material from the Vallès-Penedès Basin. Comptes Rendus Paleovol 13(4), 277-295. DOI 10.1016/j.crpv.2013.11.004

Luján, À.H., Delfino, M., Robles, J.M. \& Alba, D.M. 2016. 
A review of the Miocene tortoise Testudo catalaunica Bataller, 1926 and a revised phylogeny of extinct species of genus Testudo (Testudines: Testudinidae). Zoological Journal of the Linnean Society 178(2), 312-342.

DOI 10.1111/zoj.12414

Luján, À.H., Ivanov, M., Fortuny, J. \& SAbol, M. 2017. Fossil turtle remains from the early Miocene (MN4) localities of Mokrá Quarry (Czech Republic), 86. In YNHM: Young Natural History scientists Meeting. Paris.

Luján, À.H., Chroust, M., Čerñanský, A., Fortuny, J., Mazuch, M. \& Ivanov, M. 2019. First record of Diplocynodon ratelii Pomel, 1847 from the early Miocene site of Tušimice (Most Basin, Northwest Bohemia, Czech Republic). Comptes Rendus Palevol 18(7), 877-889.

DOI 10.1016/j.crpv.2019.04.002

LujÁn, À.H., ČerňAnský, A., Bonilla-Salomón, I., Březina, J. \& Ivanov, M. in press. Fossil turtles from the early Miocene localities of the Mokrá-Quarry (Burdigalian, MN4), Moravia, Czech Republic. Geodiversitas.

Marković, Z., Bruijn, H. DE \& Wessels, W. 2016. A revision of the new rodent collections from the Early Miocene of Sibnica, Serbia, 63-117. In Marković, Z. \& Milivojević, M. (eds) Life on the Shore-Geological and Paleontological Research in the Neogene of Sibnica and Vicinity (Levač basin, Central Serbia). Part 1. Special Issue of the Natural History Museum in Belgrade. Natural History Museum, Belgrade.

Matthew, W.D. \& Granger, W. 1923. Nine new rodents from the Oligocene of Mongolia. American Museum Novitates $102,1-10$.

Mein, P. 1958. Les mammifères de la faune sidérolithique de Vieux-Collonges. Nouvelles Archives du Muséum d'Histoire Naturelle de Lyon 5(1), 3-122.

Mein, P. 1989. Die Kleinsäugerfauna des Untermiozäns (Eggenburgien) von Maigen, Niederösterreich. Annalen des Naturhistorischen Museums in Wien 90 (A), 49-58.

Mein, P. \& Freudenthal, M. 1971. Une nouvelle classification des Cricetidae (Rodentia, Mammalia) du Tertiaire de l'Europe. Scripta Geologica 2, 1-37.

Mein, P. \& Freudenthal, M. 1981. Les Cricetidae (Mammalia, Rodentia) du Néogène Moyen de Vieux-Collonges. Scripta Geologica 60, 1-11.

Minwer-Barakat, R., García-Alix, A., Agustí, J., Martín SuÁrez, E. \& Freudenthal, M. 2009. The micromammal fauna from Negratín-1 (Guadix Basin, Southern Spain): new evidence of African-Iberian mammal exchanges during the Late Miocene. Journal of Paleontology 83(6), 854-879. DOI 10.1666/09-009.1

Oliver, A. \& Peláez-Campomanes, P. 2013. Megacricetodon vandermeuleni, sp. nov. (Rodentia, Mammalia), from the Spanish Miocene: a new evolutionary framework for Megacricetodon. Journal of Vertebrate Paleontology 33(4), 943-955. DOI 10.1080/02724634.2013.743896

Oliver, A. \& Peláez-Campomanes, P. 2014. Evolutionary patterns of early and middle Aragonian (Miocene) of Megacricetodon (Rodentia, Mammalia) from Spain. Palaeontographica Abteilung A 303, 85-135.

DOI $10.1127 /$ pala/303/2014/85
Oliver, A. \& Peláez-Campomanes, P. 2016. Early Miocene evolution of the genus Megacricetodon in Europe and its paleobiogeographical implications. Acta Palaeontologica Polonica 61(1), 211-219. DOI 10.4202/app.00099.2014

Peláez-Campomanes, P. \& Daams, R. 2002. Middle Miocene rodents from Paşalar, Anatolia, Turkey. Acta Palaeontologica Polonica 47(1), 125-132.

Pomel, A. 1848. Etudés sur les carnassiers insectivores (extrait). Seconde partie, Classification des insectivores. Archives des sciences physiques et naturelles 9, 244-251.

Pomel, A. 1853. Catalogue méthodique et descriptif des vertébrés fossiles: découverts dans le bassin hydrographique supérieur de la Loire, et surtout dans la vallee de son affluent principal, l'Allier. 193 pp. J.-B. Bailliere, Paris.

ProcházKa, V.J. 1899. Miocénové ostrovy v krasu Moravském. Rozpravy České akademie 2, 37.

QIU, Z. 1996. Middle Miocene Micromammals Faunas from Tunggur, Nei, Mongolia. 216 pp. Beijing Science Press, Beijing.

QIU, Z., LI, C. \& WANG, S. 1981. Miocene mammalian fossils from Xining Basin, Qinghai. Vertebrata Palasiatica 19(2), 156-173.

Reichenbacher, B., Krijgsman, W., Lataster, Y., Pippèrr, M., Van BaAk, C.G.C., Chang, L., Kälin, D., Jost, J., Doppler, G., Jung, D., Prieto, J., Abdul Aziz, H., Böhme, M., Garnish, J., Kirscher, U. \& Bachtadse, V. 2013. A new magnetostratigraphic framework for the Lower Miocene (Burdigalian/Ottnangian, Karpatian) in the North Alpine Foreland Basin. Swiss Journal of Geosciences 106, 309-334. DOI 10.1007/s00015-013-0142-8

Revilliod, P. 1920. Contribution à l'étude des chiroptères des terrains tertiaries: $2^{\mathrm{eme}}$ partie. Mémoires de la Société Paléontologique Suisse 44, 63-129.

Rez, J. 2003. Strukturni analýza jižni části Moravského krasu v lomech Mokrá a okoli. 45 pp. Master thesis, Masaryk University, Brno.

REz, J. 2010. Strukturně-geologický vývoj jižní části Moravského krasu. 75 pp. Ph.D. thesis, Masaryk University, Brno.

Ringeade, M. 1979. Decouverte de nouveaux Lagomorphes dans le Miocene inferieur d'Aquitaine et implications biostratigraphiques. Bulletin de l'Institut de Geologie du Bassin d'Aquitaine 26, 111-157.

Roman, F. \& Viret, J. 1930. Le Miocene continental de l'Armagnac et le gisement Burdigalien de La Romieu (Gers). Livre Jubilaire de la Société Géologique de France 2, 577-604.

Rössner, G.E. 2004. Community structure and regional patterns in late Early to Middle Miocene Ruminantia of Central Europe. In Steininger, F.F., Kovar-Eder, J. \& Fortelius, M. (eds) The Middle Miocene Environments and Ecosystem Dynamics of the Eurasian Neogene (EEDEN). Courier Forschungsinstitut Senckenberg 249, 91-100.

Sabol, M., Fejfar, O., HoráčeK, I. \& Čermák, S. 2007. The Early Miocene micromammalian assemblage from Mokrá - 1/2001 Turtle Joint site (Moravia, Czech Republic) - preliminary results. Scripta Facultatis Scientiarum Naturalium Universitatis Masarykianae Brunensis 36, 57-64.

Schaub, S. 1920. Melissiodon n. gen., ein bisher übersehener oligocäner Muride. Senckenbergiana 2, 43-47. 
Schaub, S. 1925. Die Hamsterartigen Nagetiere des Tertiärs und ihre lebenden Verwandten. Abhandlungen der Schweizerischen Paläontologischen Gesellschaft 45, 1-110.

Steininger, F.F. 1999. Chronostratigraphy, Geochronology and Biochronology of the Miocene "European Land Mammal Mega-Zones" (ELMMZ) and the Miocene "Mammal-Zones (MN-Zones)", 9-24. In Rössner, G.E. \& Heissig, K. (eds) The Miocene Land Mammals of Europe. Verlag Dr. Friedrich Pfeil, Munich.

STorch, G. 1999. Order Chiroptera, 81-90. In Rössner G.E. \& Heissig, K. (eds) The Miocene Land Mammals of Europe. Verlag Dr. Friedrich Pfeil, Munich.

Tobien, H. 1975. Zur Gebissstruktur, Systematik und Evolution der Genera Piezodus, Prolagus und Ptychoprolagus (Lagomorpha, Mammalia) aus einingen Vorkommen im jüngeren Tertiär Mittel- und Westeuropas. Notizblatt des Hessischen Landesamtes für Bodenforschung zu Wiesbaden 103, 103-186.

Van den Hoek Ostende, L.W. \& Fejfar, O. 2006. Erinaceidae and Talpidae (Erinaceomorpha, Soricomorpha, Mammalia) from the Lower Miocene of Merkur-Nord (Czech Republic, MN3). Beiträge zur Paläontologie 30, 175-203.

van der Meulen, A.J., García-Paredes, I., Álvarez-Sierra, M.Á., Van den Hoek Ostende, L.W., Hordijk, K., Oliver, A., López-Guerrero, P., Hernández-Ballarín, V. \& PeláezCampomanes, P. 2011. Biostratigraphy or biochronology? Lessons from the Early and Middle Miocene small Mammal Events in Europe. Geobios 44(2-3), 309-321. DOI 10.1016/j.geobios.2010.11.004

Vasileiadou, K. \& Koufos, G.D. 2005. The micromammals from the Early/Middle Miocene locality of Antonios, Chalkidiki, Greece. Annales de Paléontologie 91(3), 197-225. DOI 10.1016/j.annpal.2005.06.002

Venczel, M. 2004. Middle Miocene anurans from the Carpathian Basin. Palaeontographica Abteilung A 271(5-6), 151-174.
Villa, A., Abella, J., Alba, D.M., Almécija, S., Bolet, A., Koufos, G.D., Knoll, F., Luján, À.H., Morales, J., Robles, J.M., Sánchez, I.M. \& Delfino, M. 2018. Revision of Varanus marathonensis (Squamata, Varanidae) based on historical and new material: morphology, systematics, and paleobiogeography of the European monitor lizards. PLoS ONE 13, e0207719. DOI 10.1371/journal.pone.0207719

Wessels, W., Weerd, A.A., Bruijn, H. de \& Marković, Z. 2018. New Melissiodontinae (Mammalia, Rodentia) from the Paleogene of south-east Serbia. Palaeobiodiversity and Palaeoenvironments 98(3), 1-17. DOI 10.1007/s12549-017-0311-2

Zapfe, H. 1950. Die Fauna der miozänen Spaltenfüllung von Neudorf an der March (ČSR.). Chiroptera. Sitzungsberichte Österreichischen der Akademie der Wissenschaften, mathematisch-naturwissenschaftliche Klasse, Abt. I 159, 51-64.

ZIEGLER, R. 1990. Didelphidae, Erinaceidae, Metacodontidae und Dimylidae (Mammalia) aus dem Oberoligozän und Untermiozän Süddeutschlands. Stuttgarter Beiträge zur Naturkunde 158 (B), 1-99.

Ziegler, R. 1993. Die Chiroptera (Mammalia) aus dem Untermiozän von Wintershof- West bei Eichstätt (Bayern). Mitteilungen der Bayerischen Staatssammlung für Paläontologie und Historische Geologie 33, 119-154.

ZIEGLER, R. 1999. Order Insectivora, 53-74. In Rössner, G.E. $\&$ Heissig, K. (eds) The Miocene Land Mammals of Europe. Verlag Dr. Friedrich Pfeil, Munich.

Ziegler, R. 2003. Bats (Chiroptera, Mammalia) from Middle Miocene karstic fissure fillings of Petersbuch near Eichstätt, Southern Franconian Alb (Bavaria). Geobios 36(4), 447-490. DOI 10.1016/S0016-6995(03)00043-3

Ziegler, R. \& FAhlbusch, V. 1986. Kleinsäuger-Faunen aus der basalen Oberen Süßwasser-Molasse Niederbayerns. Zitteliana 14, 3-58. 